\title{
Intents and Purposes
}

\author{
Katheleen R. Guzman ${ }^{*}$
}

Question: Do you know if [the decedent] gave [his daughters] a copy of the new will?

Answer: I don't believe he did, no.

Question: Do you know why?

Answer: Well, I guess because we didn't have the completed draft without all the scribbles on it.

Question: So he thought that will was not good yet?

Answer: No, he was sure it was good, but he didn't give it to the girls. And we didn't give it to my son. We didn't give it to anybody. Question: Why?

Answer: Because it wasn't completely finished the way [the attorney] was going to finish it. ${ }^{1}$

\section{INTRODUCTION}

Within wills law, a demand for precise compliance with statutory requirements has been waning for quite some time. This is nothing new. ${ }^{2}$ Considered support for this admitted "fall of formalism" must inhere in the strength and understanding of any doctrine that rises to replace it. But so far, jurisprudential treatment of that replacement-testamentary intent-falls short of the mark.

* Orpha \& Maurice Merrill Professor of Law, University of Oklahoma College of Law. LL.M. 1992, Yale Law School; J.D. 1991, University of Arkansas School of Law. Thanks go to the University of Oklahoma College of Law for institutional support, and to Professors Mark Gillett, Emily Meazell, and Liesa Richter, and William R. Foster Jr., for sharing their insight and advice. I also thank Ms. Crys Masterson for invaluable editing assistance, and the editors of the Kansas Law Review for their excellent work on this piece. Errors are mine alone.

1. In re Estate of Hall, 51 P.3d 1134, 1136 (Mont. 2002). Under a statute requiring attested wills to be in writing and signed by the testator and two witnesses, an attempted joint will signed by both of its putative testators and notarized but not otherwise witnessed was accepted into probate as clearly and convincingly reflecting that the decedent intended it to be his will. Id. at 1135-36.

2. Twenty years ago, the Editorial Board of the Uniform Probate Code stated that a decadeslong theme in probate law was "the decline of formalism in favor of intent-serving policies." UNIF. PROBATE CODE art. II prefatory note (amended 2008), 8 U.L.A. 75 (1998). 
Testamentary intent is a piece of tricky business, with the potency both to secure probate of highly irregular documents where it exists and impede admission of closely conforming documents where it fails. As such, its significance can exceed formalistic rules of law by overriding compliance and noncompliance with the statutory requirements imposed by a given jurisdiction for the execution of a valid will. ${ }^{3}$ Coupling that constitutive force with its second-level role in will composition, construction, and revocation highlights the expanse of its power and, tautologically, the importance of identifying it in existence and extent.

That said, confluent factors can make testamentary intent an extraordinarily elusive concept. Although assorted indicators guide presumption and assessment over whether any basic "intent" exists within a particular context, both the term and the thoughts it describes are inalterably subjective. Intent may be held without any action to further it. Conversely, action may be driven by an entirely different purpose than presumed as its cause, or even occur more or less mindlessly without identifiable purpose at all. ${ }^{4}$ Given its own definitional permutations, adding the modifier "testamentary" does little to clarify things. Indeed, the imprecision that attends both words"testamentary" and "intent"-is compounded by their joinder: a will's proponent must establish that its writer wrote it with present, immediate, conditional, revocable, future, deathtime, donative, non-will substitutive, and dispositive significance ${ }^{5}$ - an already oddly paradoxical mental turn twisted even more by context. Unless the proffered document is a suicide note, its writer usually has no thoughts of its immediate consequence, and once the search for testamentary intent is on, death has already sealed her lips.

Doctrinally, some degree of inter- and even intra-jurisdictional disarray is ineluctable as the existence of testamentary intent turns on intensely subjective factors. Moreover, whether consciously or not, judges or juries seeking testamentary intent infuse personal perspectives into what should be an objective search for that subjective factor.

3. With rare exception, the relevant scholarship generally focuses on intent as adjunct to the means-ends interplay between invalid will execution and statutory compliance. See infra note 42 and accompanying text. Little discussion targets testamentary intent in its own right.

4. Simplistically, one might eat a carrot because of hunger, a desire to eat the vegetable before it goes bad, an understanding that doing so is good for one's eyes, a commitment to setting a good example for children, or a belief in the Easter Bunny. Or, one might eat a carrot simply because it is there. (1999).

5. See Restatement (Third) of Prop.: Wills \& Other Donative Transfers $§ 3.1 \mathrm{cmt}$. a 
Unfortunately, this doubled subjectivity often generates sharply different outcomes in cases with no appreciable difference in their underlying intent-reflective facets save trifling distinctions in the will's documentary language ${ }^{6}$ or the size or recipient of the estate. ${ }^{7}$

To say that that consequence is inevitable, however, misses the matter of degree and in no way absolves courts of the duty to halt or at least mitigate harm. Unpredictable outcomes encourage inefficient litigation and impose unnecessary economic and human costs on parties to it. But matters worsen when ideational difficulty and jurisdictional difference devolve into jurisprudential incoherence, which is a byproduct of concepts haphazardly defined and applied. Resultant unfairness is indeed an avoidable consequence that neither case law nor commentary has done much to rectify. While the possibility that testamentary intent will be frustrated by failure to comply with wills' formalities is well-developed, its frustration by failure to conform to its own hyper-restrictive definition is not. "There are many possible components to testamentary intent...." While "a more coherent body of law [might emerge] if we had more precise terminology for [its] different strands,"9 "no one has yet sorted [them] out."10

This Article attempts that end. Part II reviews uncontroversial extant doctrine: testamentary intent is central to a document's admission to probate and its construction thereafter. Part III reveals that the law of wills has strayed from this sine qua non by frequently failing to understand and locate testamentary intent in thoughtful, predictable ways. Part IV continues by seeking the root of that failure and concludes that the most likely but subtle culprit is the peculiar property-non-

6. Compare Estate of Blake v. Benza, 587 P.2d 271, 273-74 (Ariz. Ct. App. 1978) (admitting into probate as a holographic will a letter that admonished the recipient to "SAVE THIS"), with In re Golder's Estate, 193 P.2d 465, 466-67 (Cal. 1948) (en banc) (denying probate of a letter reading "should I get in this war and not come back I want my savings \& stock to go to you" (emphasis omitted)), and McBride v. McBride, 67 Va. (26 Gratt.) 476, 486-89 (1875) (denying probate of a purported will and letter, both of which the author requests the recipient to burn).

7. See William M. McGovern, JR. \& Sheldon F. Kurtz, Willls, Trusts and Estates: INCLUDING TAXATION AND FUTURE INTERESTS $\S 4.1$ (3d ed. 2004) (“American courts do not (at least expressly) consider who the devisees are in passing upon the formal validity of wills."). The parenthetical admission is telling. See also Melanie B. Leslie, The Myth of Testamentary Freedom, 38 ARIZ. L. REV. 235, 236-37 (1996) (asserting that courts often employ ostensibly intenteffectuating doctrine actually to thwart intent and favor family members). See generally sources cited infra note 230.

8. Jesse DuKEMinier et Al., Wills, Trusts, AND Estates 250 (7th ed. 2005).

9. James Lindgren, The Fall of Formalism, 55 ALB. L. REV. 1009, 1017 (1992) [hereinafter Lindgren, Formalism].

10. DUKEMINIER ET AL., supra note 8, at 250. 
property nature of the testamentary beast itself. Intent loses both deliberateness and expressive clarity where action upon it, such as writing a will, holds little immediate consequence for either a particular testator or the beneficiaries she hopes to enrich. ${ }^{11}$

The history of relevant litigation displays that clumsy intent doctrine is nothing new and might have worked "well enough" when a failure to comply with the stated rules essentially foreclosed further discussion of its presence. But more precise tools construct more precise things and usually at a lower eventual cost. More importantly, they permit users to bring design to fruition and intent to purpose far more reliably than cumbersome instruments allow. A deepened understanding of testamentary intent has always been worth the effort. Still, it is more critical now than ever given the enhanced role that intent plays in reducing a will's formalities and tempering or even excusing documentary defects. Further, new technologies, expanded definitions of writings and signatures, ${ }^{12}$ broader entryways for extrinsic evidence, and ever-proliferating will substitutes ${ }^{13}$ will alter the methods of its expression in ways that may well require enhanced understanding of the term. Refining testamentary intent as defined and applied facilitates Part V's attempt to reorder its structure and use. Testamentary intent should be non-formalistic, rejecting the convention that its holder intends a precise match between it and the particular document at hand. Moreover, it should be more easily found, with forgiving evidentiary hurdles over both the standard of proof demanded for its determination and the sources from which it may be drawn.

11. Introductory discussion during the fall 2010 semester of my Wills \& Trusts class vividly made this point. I asked students to explain the relatively low incidence of testate death, even among lawyers. To paraphrase one student's response, "It is because writing a will does not really seem to make an immediate difference to anyone. I will retain the same rights to the property after I have made a will as I had possessed before - nothing lost. The same holds true for the people I write into my will—nothing gained.”

12. The Electronic Signatures in Global and National Commerce Act permits electronic records and signatures in certain contexts, but specifically excludes wills, codicils, and testamentary trusts. 15 U.S.C. $\S \S 7001,7003(a)(1)$ (2006). Nevada is the only state to have passed an electronic wills statute. Nev. Rev. StAT. ANN. § 133.085 (West Supp. 2011). See generally Joseph Karl Grant, Shattering and Moving Beyond the Gutenberg Paradigm: The Dawn of the Electronic Will, $42 \mathrm{U}$. MICH. J.L. REFORM 105 (2008) (discussing the bases for the writing requirement and advocating recognition of electronic wills).

13. For example, although a trust generally requires a res and a will amendment generally requires reexecution, modern statutes permit a valid will to pour a mere expectancy interest into an otherwise-unfunded trust, then functionally amend that will each subsequent day without meeting reexecution or other wills law requirements, simply by amending the trust. Testamentary intent for the will is key to the plan's success. Unif. Testamentary AdDitions to Trusts Act $\S 1$ (amended 1991), 8B U.L.A. 360 (1998). 
Attempting fuller understanding of testamentary intent is free and easy, but restructuring content-based, procedural, and evidentiary rules is not. More flexible intent standards might be feared as precision antithesis, engaging courts in otherwise procedurally avoidable litigation and rendering mistake-laden outcomes in finding a will where none was intended. But rigid, arguably unfair standards create similar vulnerability to mistake, but with outcomes flowing in the other direction. Where perfection is unattainable, this "hard place" "between over- or under-inclusion errors" is familiar yet frighteningly irreversible. That said, selecting rules that risk over-inclusion by favoring the identification of testamentary intent-and therefore wills - is the better choice: no one will die for courts having done so. Testamentary-enough intent more than likely exists anyway, and to some extent, responsibility for any marginal misstep in finding it would rest appropriately with the decedent who had left evidence to that effect in the first place.

Efficiency arguments aside, discerning and classifying a particular decedent's intent in writing a particular document improves appropriate regard and immediate results for that decedent, her estate, and those she holds dear. Doing right by individual citizens is a decent end in itself. But revitalized intent doctrine also respects property rules and the simultaneously individualistic and collective freedoms they hold close. Such values deserve mindfulness wherever they arise, and the many crossroads captured by testamentary intent make it a valuable vehicle for attention.

\section{THE NECESSITY AND BREADTH OF TESTAMENTARY INTENT}

Intent is indisputably the heart of the will,

the queen or empress of the testament; because the will doth rule and govern the testament, enlarge and restrain it, and in every respect moderate and direct the same, and is indeed the very efficient cause thereof. The will, therefore, and meaning of the testator ought before all things to be sought for diligently, and being found ought to be observed faithfully. And as to the sacred Anchor ought the judge to cleave unto it, pondering not the words but the meaning of the testator. For although no man be presumed to think otherwise than he speaketh, yet cannot every man utter all that he thinketh, and therefore are his words subject to his meaning. And as the mind is before the voice, (for 
we conceive before we speak), so is it of greater power; for the voice is to the mind as the servant is to the lord. ${ }^{14}$

These words capture the centrality of testamentary intent to the entire probate enterprise, particularly when seeking what a will's writer meant, but they obscure a fundamental feature of doctrine. An ordinary document can be construed as soon as it is written. A will, however, cannot-nor may one raise questions of its composition, construction, or revocation-until initially found to exist. It is therefore useful to separate the discrete but overlapping primary and secondary functions that testamentary intent serves: driving the original finding of the will, with its construction deferred to thereafter. Doing so recognizes that while intent may always have controlled in the latter function, its operational position vis-à-vis the formal rules invoked in finding that a will even exists has shifted from one of subordination, to relative equilibrium, to a current level of dominance compelling analytic care.

\section{A. Primary Purposes: The Constitutive Properties of Testamentary Intent}

With mitigating principles later discussed, a proffered document generally requires two components to qualify as a will: testamentary intent and formalities. ${ }^{15}$ Intent is expressed as but half of the equation. While overwhelming evidence of its existence may soften the rigor with which statutory compliance is assessed, traditional rules preclude the raising of a non-compliant document to the status of an effective will. ${ }^{16}$

14. In re Estate of Shults, No. M2006-02013-COA-R3-CV, 2008 WL 490643, at *5 (Tenn. Ct. App. Feb. 22, 2008) (quoting 1 JACK W. ROBINSON, PRITCHARD ON THE LAW OF WILLS AND ADMINISTRATION OF ESTATES $§ 404$ (6th ed. 2007)).

15. Restatement (Third) OF Prop.: Wills \& Other Donative Transfers $\S 3.1 \mathrm{cmt}$. $\mathrm{f}$ (1999) ("Executing a valid [attested] will requires the testator to manifest an intent to make a will and to comply with specified statutory formalities." (citation omitted)); id. §3.2 cmt. c ("Holographic wills as well as attested wills must be executed with testamentary intent.”); $c f$. Sewell v. Slingluff, 57 Md. 537, 546 (1882) ("There are three essential requisites for every good and valid will; and these requisites are, perfect testamentary capacity, the intention to dispose of property in the event of death, and the formalities required by the statute.").

16. See, e.g., In re Abrams' Will, 77 P.2d 101, 103 (Okla. 1938) ("It is to be regretted that the intention of the testatrix is defeated by her failure to observe the statutory requirements, but to hold otherwise would in effect be to let down the bars to evils against which the statutory provisions are aimed."). 
The converse is also true, although with less attention paid it. ${ }^{17} \mathrm{~A}$ document bearing all statutory formalities might raise a pragmatic ${ }^{18}$ or legal ${ }^{19}$ presumption that testamentary intent exists. Nevertheless, establishing its absence will usually prevent a will's admission to probate or affect its vitality thereafter. ${ }^{20}$

17. See, e.g., Clark v. Hugo, 107 S.E. 730, 733 (Va. 1921) ("The mere fact of [required acts], though strictly in accord with the requirements of the statute, is not conclusive upon [whether a will exists]. There must have been a testamentary intent.”), overruled in part by Poindexter v. Jones, 106 S.E.2d 144 (Va. 1958); see also McBride v. McBride, 67 Va. (26 Gratt.) 476, 481 (1875) (“Unless [testamentary intent satisfactorily] appear[s], the paper must be rejected, however correct it may be in its form, however comprehensive in its details, however conformable to the otherwise declared intentions of the party, and although it may have been signed by him with all due solemnity." (internal quotation marks omitted)).

18. This is particularly true for attorney-assisted drafting and execution. For example, a typical document would include the caption "Last Will and Testament" and continue restating the document's purpose, such as, "I, John Doe ... do hereby make, publish and declare this to be my Last Will and Testament hereby revoking all Wills and Codicils heretofore made by me.” JEROME IRA SOLKOFF, 18A WeST's LEgAL FORMS, ELDERLAW § 4.206 (3d ed. 2010). Moreover, the ceremony might include recitation of, and the document would probably close with, an attestation clause and a self-proving affidavit reaffirming testamentary intent and securing other proofs. See, e.g., MCGOvern \& KURTZ, supra note 7, at 183-84 (discussing functions of formalities). Few people would undergo such ceremony without holding testamentary intent. Moreover, no contestant could assert the absence of intent if the best or even sole evidence of its non-existence had died with the decedent.

19. Some courts presume testamentary intent for documents meeting statutory requirements. See generally W.E. Shipley, Annotation, Admissibility of Extrinsic Evidence upon Issue of Testamentary Intent, 21 A.L.R.2d 319 (1952) (collecting cases that consider whether extrinsic evidence is admissible to establish testamentary intent). Some courts have gone further:

When [statutorily prescribed] formalities are observed,... the statute in itself and of itself attaches, and conclusively attaches, the animus testandi. The requisition of extrinsic or additional evidence of its existence is to add to the requirements of the statute; and to receive such evidence to repel the existence of the intent would be to receive evidence against the statute.

Barnewall v. Murrell, 18 So. 831, 839 (Ala. 1895). Similarly, in In re Smith's Estate, the court found that a statutorily compliant writing "of itself imports, and conclusively imports, the animus testandi, i.e., the mind to dispose, the firm and advised determination to make a testament, closing all inquiry as to the existence and manifestation of the intent.” 14 N.W.2d 71, 74 (Mich. 1944) (en banc) (quoting Barnewall, 18 So. at 839) (internal quotation marks omitted).

The Restatement (Third) of Property tempers things, providing that the clear expression of testamentary intent "raises a strong (but not irrebuttable) presumption" of testamentary intent, itself rebuttable by "clear and convincing" evidence. RESTATEMENT (THIRD) OF PROP.: WILls \& OTHER DONATIVE TRANSFERS § $3.1 \mathrm{cmt}$. g (1999).

20. See, e.g., In re Sargavak’s Estate, 216 P.2d 850, 851-52 (Cal. 1950) (en banc) (per curiam) (noting that even instruments seemingly expressing testamentary intent may be proven by extrinsic evidence to have lacked it, such as through jest, threat or coercion, initiation rite, mistake, or hypothetical); Fleming v. Morrison, 72 N.E. 499, 499-500 (Mass. 1904) (finding no testamentary intent where a will was executed solely to induce beneficiary's sexual relationship with testator). This is the majority view, as Professors Langbein and Waggoner note that "most Anglo-American courts will consider [whether testamentary intent exists] on the merits." John H. Langbein \& Lawrence W. Waggoner, Reformation of Wills on the Ground of Mistake: Change of Direction in 
The early English case of Lister v. Smith ${ }^{21}$ instructs. The proponent offered a technically perfect document as a codicil to a prior will. ${ }^{22}$ The court nevertheless accepted parol evidence, including the testator's alleged lifetime statements, that the codicil's sole function was not to alter his testamentary disposition but rather to pressure a third party's conduct while he was alive. ${ }^{23}$ Although he admitted that the case had given him "some anxiety" and remonstrated that courts must "guard with jealousy the sanction of a solemn act" through evidence both "cogent and conclusive," ${ }^{24}$ Sir J.P. Wilde nevertheless ruled against the codicil:

The momentous consequences of permitting parol evidence thus to outweigh the sanction of a solemn act are obvious. It has a tendency to place all wills at the mercy of a parol story that the testator did not mean what he said. On the other hand, if the fact is plainly and conclusively made out, that the paper which appears to be the record of a testamentary act, was in reality the offspring of a jest, or the result of a contrivance to effect some collateral object, and never seriously intended as a disposition of property, it is not reasonable that the Court should turn it into an effective instrument. And such no doubt is the law. There must be the animus testandi. ${ }^{25}$

Intent and formalities, each critical, have thus often worked in tandem. One may exist, or the other; both, or neither. Casting them in counterpoise, as is often done, suggests that each component has always held equal weight in assessing a document for probate. In reality, intent usually surrendered to formalities, an imbalance apparent in the asymmetry of some of this doctrine and, if listening hard, even in the language of the cases themselves. For example, proof of compliance with formalities connotes or conclusively presumes that testamentary intent exists, whereas an even overwhelming body of proof establishing testamentary intent speaks very little to whether-and certainly raises no legal presumption that-the proffered document meets statutory formalities. In both instances, formalities traditionally held the upper hand, yet it is both more likely and more devastating to have testamentary intent without the formalities than the reverse. This

American Law?, 130 U. PA. L. Rev. 521, 541-42 (1982); see also 1 PAGE ON THE LAW OF WILLS $\S 5.16$ (2003) ("[B]y the majority view[,] parol evidence is admissible to show jest, joke and sham.”).

21. (1863) 164 Eng. Rep. 1282 (P.D.), 3 Sw. \& Tr. 282.

22. Id. at 1285,3 Sw. \& Tr. at 287.

23. Id. at $1285,3 \mathrm{Sw}$. \& Tr. at $287-88$.

24. Id. at 1285,3 Sw. \& Tr. at $287,289$.

25. Id. at 1285-86, 3 Sw. \& Tr. at 288, 290-91. 
observation simultaneously supports the ever-increasing role that intent now serves and demands its correlatively increased care.

\section{Wills Formalities and Intent}

Assuming temporarily that testamentary intent has been formed, a particular formal manner of its expression is either evidence of its existence - a standard - or the sole means to its legal effectuation-a rule. That wills law traditionally embraces the latter approach counsels review of those formalities, their interplay with intent, and the interstitial goals they are thought to achieve.

There are three staples to a valid will: (1) a writing (2) signed by the testator and (3) signed by a specified number of witnesses. ${ }^{26}$ Variations exist. Some jurisdictions require that the testator sign the writing at its end, or "subscribe," by contrast to its acceptance anywhere within the will that the decedent's handwritten name appears. ${ }^{27}$ Differences remain over what third parties must observe before achieving witness status. Common options include the testator's act of signing, the testator's later acknowledgment of a prior signature, or the testator's later acknowledgment of the document as a will. ${ }^{28}$ As these distinctions suggest, jurisdictions also vary on the physical relationship required among the testator and witnesses at assorted ceremonial points. ${ }^{29}$

26. Restatement (THIRD) OF Prop.: Wills \& Other Donative Transfers § 3.1 (1999).

27. See, e.g., OHIo Rev. Code AnN. § 2107.03 (West 2005); 20 Pa. Cons. STAt. AnN. § 2502 (West 2005). Subscription can be relevant even when the statute only requires signature, as by assessing whether the decedent's handwritten name in an exordium clause would well-enough express either authenticating intent for the signature or testamentary intent for the will. See, e.g., Hoffman v. Hoffman, 18 N.E. 2d 209, 210-11 (Ill. 1938); RESTATEMENT (THIRD) OF PROP.: WiLlS \& OTHER DONATIVE TRANSFERS $§ 3.1 \mathrm{cmts}$. j, k (1999) (discussing the effect of handwritten name and the general rule against freestanding signatures without other evidence to the testator's intent).

28. See, e.g., Unif. Probate Code § 2-502(3) (amended 2008), 8 U.L.A. 144 (Supp. 2011). Acknowledgment of the document as a will is the functional equivalent of the publication demanded in some jurisdictions where the testator expressly or impliedly "declares" to the witnesses that the subject instrument is her will, so it does not require that its contents be revealed. See, e.g., IowA CODE ANN. § 633.279 (West 1992) ("An attested will may be made self-proved at the time of its execution, or at any subsequent date, by the acknowledgment thereof by the testator and the affidavits of the witnesses ....”); TENN. CODE ANN. § 32-1-104 (West 2009) (permitting testator to signify to attesting witnesses that instrument is testator's will by acknowledgment of testator's signature). Note, however, the effect of will acknowledgment or publication on testamentary intent: for either to occur, the publisher must have held it. See, e.g., id.

29. See, e.g., 2 PAGE ON THE LAW OF WILLS $§ 19.126$ (2003) (discussing requirements of physical proximity between witnesses and blind testator). Aside from state-specific rules about who must be in the presence of whom and when, less easily answered is the meaning of "presence" itself. Some jurisdictions, including those enacting the Uniform Probate Code, merely require one to be in the "conscious presence" or "within the range of senses" of the other. See, e.g., Cunningham v. 
Every jurisdiction accepts the "attested" or witnessed will, which rarely leaves room for question over testamentary intent. Most states, however, also recognize one or more less formal-thus potentially less reliable-methods of its expression. More than half allow the holographic or unattested will ${ }^{30}$ by accepting into probate a handwritten and unwitnessed document that has been signed by the decedent. ${ }^{31}$ Twenty-one jurisdictions allow nuncupative or oral wills, ${ }^{32}$ although certain constrictions greatly curtail their utility. ${ }^{33}$

\section{Mediating Formalities and Intent}

Legal requirements for effecting a valid testamentary disposition are absurd unless they serve relevant ends. The authoritative work of Ashbel Gulliver and Catherine Tilson, later extended by John Langbein, recognizes the intermediate goals of execution formalities as protective, evidentiary, cautionary, and channeling, which in turn target the ultimate identification and effectuation of the decedent's testamentary intent. ${ }^{34}$

Cunningham, 83 N.W. 58, 59-60 (Minn. 1900) (finding conscious presence where "[t]he signing was within the sound of the testator's voice"). Stricter jurisdictions embrace the "line of sight or vision" test, under which one must see or have been able to see the other's specific act had she looked. See, e.g., Newton v. Palmour, 266 S.E.2d 208, 209-10 (Ga. 1980) ("In order for the will to be signed by the subscribing witnesses 'in the presence of' the testator, ... it is enough that the testator, without changing his position, might have seen the will being attested . ...”).

30. Twenty-seven states generally recognize the holographic will. Steven Clowney, In Their Own Hand: An Analysis of Holographic Wills and Homemade Willmaking, 43 REAL PrOP. TR. \& EST. L.J. 27, 34 \& n.25 (2008) (gathering state statutes that recognize holographic wills). See generally MCGOVERN \& KURTZ, supra note 7, § 4.4 (discussing the requirements of holographic wills). For statutory specifics, see Restatement (THIRD) OF PROP.: WiLls \& OTHER DONATIVE TRANSFERS § $3.2 \mathrm{cmt}$. a (1999).

31. Jurisdictional differences roughly sort into first-, second-, and third-generation schemes. Restatement (ThiRd) OF Prop.: Wills \& Other DONATIVE Transfers § 3.2 cmt. a (1999). First-generation statutes essentially demand the will to be "entirely" or "wholly" in the decedent's handwriting and often also require a date. Id. Second- and third-generation statutes require only that the will's material "provisions" or "portions," respectively, be in the decedent's handwriting. Id.

32. See generally id. § 3.2 statutory note 1 .

33. Oklahoma's statute is typical: oral wills are limited to personal property not valued over $\$ 1,000$; the will must be proved by two persons present at its declaration, one of whom must have been asked by the testator to witness it; and the testator must have been actually engaged in military service and suffer fear, actual peril, or expectation of imminent death. OKLA. STAT. ANN. tit. 84, $\S \S 46,51$ (West 2003). They must be reduced to writing within thirty days and offered for probate within six months of utterance. OKLA. STAT. ANN. tit. 58, § 91 (West 2003).

34. Ashbel G. Gulliver \& Catherine J. Tilson, Classification of Gratuitous Transfers, 51 YALE L.J. 1, 5-13 (1941); John H. Langbein, Substantial Compliance with the Wills Act, 88 HARV. L. REV. 489, 491-98 (1975) [hereinafter Langbein, Substantial Compliance]. 
So viewed, a will's formalities offer protection in one form or another-generally, protecting the decedent's testamentary intent; conjunctively, protecting the decedent from the system, others, and herself; protecting the system from complexity and wasteful litigation; and protecting third parties with interest in the estate. Formalities serve evidentiary functions by providing a reliable written and often witnessed expression of the decedent's intent. ${ }^{35}$ The cautionary function shields the decedent from her own caprice or improvidence by imposing ceremonial safeguards, such as subscription and publication, to ensure that the endeavor was considered and deliberate. ${ }^{36}$ Attestation modestly contributes to the protective function by deterring the incidence or ease of others' wrongful interference with intent. ${ }^{37}$ And by normalizing the form through which it is expressed, the channeling function provides a recognizable legal framework for both testamentary intent and the act designed to achieve it. ${ }^{38}$ The interplay between formality and function is both self-supporting and mutually reinforcing.

Debate continues over whether the access benefits conferred by holographic wills outweigh their evidentiary and functional costs. ${ }^{39}$ Whether they should exist, that they presently do in a majority of states ${ }^{40}$ suggests a not-insignificant legislative confidence in their propriety as a transfer form and thus their ability to convey and effectuate fully formed intent. Moreover, if the current set of formalities for attested wills overprotects anyway, ${ }^{41}$ then the holograph might deserve celebration for its populism, rather than mere tolerance as a legal annoyance owing more to inertia than policy.

In establishing a rule-goal relationship, one extreme would superordinate a heavy dose of formalism to the virtual exclusion of intent

35. Langbein, Substantial Compliance, supra note 34, at 492-93.

36. Id. at 495.

37. Gulliver \& Tilson, supra note 34 , at 10.

38. See Emily Sherwin, Clear and Convincing Evidence of Testamentary Intent: The Search for a Compromise Between Formality and Adjudicative Justice, 34 ConN. L. REV. 453, 456 (2002) (noting that "if formality requirements are well chosen to provide reliable evidence, ensure a wellconsidered decision, and protect against imposition, effective channeling will enhance the beneficial evidentiary, cautionary, and protective effects of the rules”).

39. See, e.g., Richard Lewis Brown, The Holograph Problem-The Case Against Holographic Wills, 74 TENN. L. REV. 93, 126-27 (2006) (concluding that "holographic wills are more trouble than they are worth”); Clowney, supra note 30, at 31-32, 71 (defending the holograph against claims that it is an inherent litigation-producer).

40. See Clowney, supra note 30 , at 34 \& n.25 (gathering state statutes that recognize holographic wills).

41. See Jane B. Baron, Gifts, Bargains, and Form, 64 IND. L.J. 155, 159 (1989). 
by assuming that the sole assurance that testamentary intent had been formed and exercised would be to identify a set of rigid rules and then demand their strict compliance. This approach effectively treats requirements as ends in themselves. While such crystallization might create transaction and litigation efficiencies, it places an inordinate premium on the intent-reflective ability of one precise set of requirements to establish intent. Further, this too often occurs at the expense of a particular decedent's actual wishes. If the channel is too narrow, no one will get through. The older cases reflecting this view, along with some more recent examples, are legion, well-documented, and deserve the disparagement they invite. ${ }^{42}$

The other extreme would discard all rules to favor underlying intent in each individual case and permit its showing in any form, irrespective of its oral or written expression or even original manifestation at all. This design suffers its own weaknesses and does not enjoy support by even the most ardently intent-driven advocates. ${ }^{43}$ While an ad hoc, pure intent approach would obviously uphold intent as paramount, it would do so at the cost of vastly increased likelihood of error or fraud in its creation, assertion, or scope, and litigation over the "answers" to each. The first approach looks like a lockdown; the latter, a free-for-all. Testamentary intent remains within the equation both ways, but as tilted way up or way down on the fulcrum of the document's admission.

42. The absurdities generated by rigidity, variously labeled mechanical, silly, dishonest, harsh, relentless, unfair, and even unforgiveable, are comprehensively recounted in influential sources. See, e.g., John H. Langbein, Curing Execution Errors and Mistaken Terms in Wills: The Restatement of Wills Delivers New Tools (and New Duties) to Probate Lawyers, ProB. \& Prop. Jan.-Feb., at 28, 28 (2004) [hereinafter Langbein, Curing Execution Errors] (using the example of a will invalidated because a witness prematurely left to use the washroom); John H. Langbein, Excusing Harmless Errors in the Execution of Wills: A Report on Australia's Tranquil Revolution in Probate Law, 87 Colum. L. REv. 1, 3-4 (1987) [hereinafter Langbein, Excusing Harmless Errors] (providing examples of formalism defeating intent); James Lindgren, Abolishing the Attestation Requirement for Wills, 68 N.C. L. REV. 541, 545 n.30 (1990) [hereinafter Lindgren, Attestation Requirement] (same); Lindgren, Formalism, supra note 9, at 1011-12 (same); Bruce H. Mann, Essay, Formalities and Formalism in the Uniform Probate Code, 142 U. PA. L. REV. 1033, 1036 (1994) [hereinafter Mann, Probate Code] (same); Bruce H. Mann, Self-Proving Affidavits and Formalism in Wills Adjudication, 63 WASH. U. L.Q. 39, 47-48 (1985) [hereinafter Mann, Wills Adjudication] (same); C. Douglas Miller, Will Formality, Judicial Formalism, and Legislative Reform: An Examination of the New Uniform Probate Code "Harmless Error" Rule and the Movement Toward Amorphism, 43 FLA. L. REV. 167, 222-29 (1991) (same); J.G. Miller, Substantial Compliance and the Execution of Wills, 36 INT’L \& CoMP. L.Q. 559, 561-62 (1987) (same).

43. See Langbein, Excusing Harmless Errors, supra note 42, at 6 ("To eliminate hardship without altering the rule of strict compliance would require abolishing the Wills Act formalities entirely. But a legal system should be able to preserve relatively high levels of formality, in order to enhance the safe harbor that is created for the careful testator who complies fully, without having to invalidate every will in which the testator does not reach the harbor.”). 


\section{Mediating the Extremes}

Middle ground exists. For example, jurisdictions could retain many formalities but temper their stridency through the substantial-compliance doctrine, reduce the number of rules with which testators must comply but retain strict compliance for those that remain, ${ }^{44}$ or relax both levels with fewer rules and looser compliance standards. These options essentially place rules and intent on roughly equal footing and correct some of the rule-heavy imbalance earlier described. Indeed, whenever the law favors formalities over desire or when their equivalence truly exists, there is no need for severely heightened assessment of intent: its presence will either be presumed (through rule compliance) or irrelevant (by strict default), or it will, on balance, guide determination over whether the rules (or their intermediate goals) have been met "enough.”

But here is where intent has surged. The Restatement (Third) of Property and the 2008 iteration of the Uniform Probate Code (UPC) have tilted acutely toward intent by stripping rules to a minimum ${ }^{45}$ and, more importantly, permitting even the few left standing to be dispensed with entirely upon clear and convincing evidence "that the decedent intended

44. This seems to have been the approach taken by the 1969 Uniform Probate Code:

The Code's approach was not to encourage courts to abandon their strict construction of the formalities prescribed, but rather to reduce the number and refine the scope of those formalities so that, if strict construction were employed, "inequities" in individual cases would occur less frequently and would be justified by the importance of the interests protected by the formal requirements that were retained.

In re Estate of Peters, 526 A.2d 1005, 1009 (N.J. 1987). The facts of Peters provide a good example. The court noted that its will-execution statute had been "rife with... formal encrustations" before amendment in 1978 removed certain presence requirements for validity. Id. at 1009-10. But in refusing to probate a will signed after the decedent's death, the court observed:

It cannot be overemphasized that [by its amendments,] the Legislature ... did not dispense with the requirement that the execution of a will be witnessed. Indeed, it is arguable that as the number of formalities have been reduced, those retained by the Legislature have assumed even greater importance, and demand at least the degree of scrupulous adherence required under the former statute.

Id. at 1010. The New Jersey Supreme Court later adopted the substantial-compliance doctrine in In re Will of Ranney. 589 A.2d 1339, 1346 (N.J. 1991). The legislature later codified the harmlesserror exception. N.J. STAT. ANN. § 3B:3-2 (West Supp. 2011).

45. For example, under section 2-502(a) of the Uniform Probate Code, an attested will must merely be written and signed by the testator or a proxy, and it must also either be (1) signed by two others within a reasonable time of witnessing the testator's signature, acknowledgment of the signature, or acknowledgment of the will, or (2) acknowledged by the testator before a notary or other legally authorized person. 8 U.L.A. 144 (Supp. 2011). Thus, there are no overt requirements of publication, subscription, request to sign, or presence between the testator, the witnesses, and each other. 
the document or writing to constitute... the decedent's will."46 The presumable result is that more wills will be admitted to probate: (1) a larger number will initially conform to formal requirements; (2) of those that do not, fewer would-be contestants will determine that payoff warrants litigation risks and costs; and (3) some percentage of actually challenged documents will be saved by the dispensing-power backstop such as through the colloquy with which this Article began.

Because both the UPC and the Restatement retain rules, ramp up proof of intent in their absence to "clear and convincing," 47 and cast the dispensing power as an exception to formalities rather than an initial open-ended standard, they fall short of representing undiluted intent. ${ }^{48}$ Its power, however, is undeniable. And gates swing both ways. Because testamentary intent has assumed such dominance in an apparently upward trajectory $^{49}$ and as compounded by rule relaxation in other

46. UnIF. Probate CodE § 2-503 (amended 2008), 8 U.L.A. 146 (1988). This provision apparently applies in seven states: Colo. REV. STAT. ANN. § 15-11-503 (West 2009); HAW. REV. STAT. § 560:2-503 (West 2008); MiCH. COMP. LAWS ANN. § 700.2503 (West 2006); MonT. CODE ANN. § 72-2-523 (2011); N.J. STAT. ANN. § 3B:3-3 (West 2007); S.D. CODIFIED LAWS § 29A-2-503 (2004); UTAH CODE ANN. § 75-2-503 (West 2004).

47. The drafters assert that by placing the burden of proof upon the proponent and requiring its discharge to be "policed with rigor" through clear and convincing evidence rather than the usual preponderance standard, "[s]ection 2-503 imposes procedural standards appropriate to the seriousness of the issue.” UNIF. PROBATE CODE § 2-503 cmt. (amended 2008), 8 U.L.A. 147 (1998). As is later discussed, this provision arguably grants with one hand what it takes by the other, which it then places too heavily upon the intent-formality scale. See infra note 229 and accompanying text.

48. See id. For example, while the Uniform Probate Code is technically agnostic on point, its commentary suggests that both documentary writings and signatures are indispensable. Id. § 2-502 cmt. As a practical matter, most documents capable of supporting clear and convincing proof of their writers' intent to endorse them as wills will probably meet many, if not all, of the formalities anyway.

An interesting comparison can be drawn with the Uniform Probate Code section 2-513, as amended in 2008, under which an unattested but signed non-holographic document disposing of non-cash personal property might be given testamentary effect if the decedent's will referred to it. 8 U.L.A. 158 (1998). Aside from noting that the list itself could not possibly meet section 2-503 standards, the original provision permitting the document to be unsigned was modified in 1990 on the theory that unsigned documents do not provide as much evidence of testamentary intent as signed ones. See, e.g., Restatement (ThIRD) OF Prop.: Wills \& OTHER DonAtive Transfers $\S 3.9$ (1999) (providing that a will may devise property even though it does not meet the elements of incorporation by reference).

49. See, e.g., MCGOVERN \& KURTZ, supra note 7, § 4.1 (discussing "liberalizing trend" in wills requirements law); Clowney, supra note 30, at $37 \&$ n.42 (noting the submerged trend of increased acceptance of holographs, which inherently favor intent over formalities). Although few states have adopted dispensing power, both the Uniform Probate Code and the Restatement hold sway beyond enactment borders. See, e.g., UNIF. PROBATE CODE prefatory note (amended 2008), 8 U.L.A. 364 (noting that it has been "enacted in close to complete form in about twenty states but influential in virtually all”); Roger W. Andersen, The Influence of the Uniform Probate Code in Nonadopting 
contexts, ${ }^{50}$ defining it and its boundaries has become essential whether one's motivation is to enhance a document's admission to probate or impede it.

In addition to tracing the ascendance of intent, this overview of wills law suggests some of the doctrinal perversity to follow. Courts will find testamentary intent in documents and perhaps admit them to probate even when they do not comply with stated rules, and disaffirm testamentary intent to deny probate to attested documents even when they do. Their readiness to both override the presumptive intent created by perfect formalities, yet find intent in their absence, exposes the weakness of claiming that acts, intents, and purposes will always perfectly align. And yet, aside from its acknowledged importance, particularly for partially or fully holographic instruments, courts routinely resist finding testamentary intent-even when the document does comply with stated rules and no evidence of sham intent exists-by legalistically cramping its definition, limiting sources of proof, and heightening burdens of its establishment.

\section{B. Secondary Purposes: The Constructional Properties of Testamentary Intent}

\section{Will Composition}

In addition to its growing centrality to a will's creation, intent figures prominently in a series of loosely grouped doctrines aimed at discerning the acts or documents that constitute the will. Under integration, a will initially comprises any pages actually present at execution and intended to be a part of it. ${ }^{51}$ Two intents are therefore required: testamentary and "integrative." Relatedly, an extrinsic document that is not physically present at execution can be incorporated into a will that reflects

States, 8 U. PUGET SOUND L. REV. 599, 599 (1985) (noting that legislatures in fourteen states have adopted the Uniform Probate Code).

50. See, e.g., Richard F. Storrow, Judicial Discretion and the Disappearing Distinction Between Will Interpretation and Construction, 56 CASE W. RES. L. REV. 65, 66-67 (2005) (lamenting the growing tendency of modern courts to collapse will construction and interpretation with over-flexibility and "limitless discretion," and noting the "increasing[] relax[ation]" of rules over the admission of extrinsic evidence).

51. See Restatement (Third) OF Prop.: Wills \& Other DonAtive Transfers § 3.5 (1999). For examples of this doctrine applied, see Walsh v. St. Joseph's Home for the Aged, 303 A.2d 691 (Del. Ch. 1973), and In re Estate of Beale, 113 N.W.2d 380 (Wis. 1962). 
incorporating intent and sufficiently describes the document. ${ }^{52}$ Again, two intents are needed: testamentary and "incorporating."

The doctrine of acts with independent significance completes generic will provisions with conduct. ${ }^{53}$ For example, the effect of a will stating "whatever car I own at my death to my widow" could change over time depending on the testator's conduct in buying and selling cars and in marrying and divorcing people. Although such conduct functionally works as a post-execution amendment to the will, reexecution is unnecessary if the acts were intended to hold significance distinct from the will itself. ${ }^{54}$

Each doctrine involves second-level intent inquiries but also, in varying degrees, inquiry into whether original testamentary intent exists at all. The number, existence, and source of documents or acts to be effectuated within probate are irrelevant without a purported willsomething must anchor testamentary intent to any candidate for integration or incorporation. The presence of that primary intent often turns on the subsidiary doctrines themselves, as where two arguably testamentary documents exist, but alone neither sufficiently reflects intent nor adequately complies with the rules.

\section{Will Construction and Revocation}

Upon the establishment of a will and its composite parts, intent remains key but takes a slightly different thrust. No longer employed to assess whether the decedent intended the subject document to be a will, it now illuminates its meaning with principals of interpretation and construction.

Here, intent reigns supreme and, unlike its role in will formation, arguably always has. For example, contrary to older doctrine explicitly

52. Restatement (Third) of Prop.: Wills \& Other Donative Transfers § 3.6 (1999); see, e.g., In re Estate of Came, 529 A.2d 962, 964-65 (N.H. 1987) (describing the requirements to incorporate a document into a will by reference); In re Estate of Shults, No. M2006-02013-COA-R3CV, 2008 WL 490643, at *6 (Tenn. Ct. App. Feb. 22, 2008) (providing that a document can be incorporated if properly identified and the court determines it is the intent of the decedent). Some jurisdictions demand further that the writing both actually exist and be expressly referred to as existing in the will. See, e.g., In re Estate of Meskimen, 235 N.E.2d, 619, 622 (Ill. 1968) (adopting the additional requirement); In re Estate of Erbach, 164 N.W.2d 238, 242-43 (Wis. 1969) (noting but not adopting additional requirement). The Uniform Probate Code relaxes these requirements by embracing the "2-513 list." See Unif. Probate CodE § 2-513 (amended 2008), 8 U.L.A. 158.

53. RESTATEMENT (THIRD) OF PROP.: Wills \& OTHER DONATIVE TRANSFERS $\S 3.7$ (1999).

54. See id. 
biased toward heirs over beneficiaries, ${ }^{55}$ modern jurisprudence generally furthers, sometimes statutorily, construction so as to avoid intestacy and place the testator's intent above all comers. Unfortunately, the application of such rules is usually inapposite to primary testamentaryintent determination; the rules usually apply to interpret a valid will rather than legitimize an otherwise marginal document. ${ }^{56}$ For example, in In re Will of Smith, the appellate court invoked the doctrine of probable intent to find that a holographically compliant letter to an attorney should constitute a will. ${ }^{57}$ The New Jersey Supreme Court reversed. ${ }^{58}$ The court admonished that "the doctrine of probable intent is available only to interpret, but not to validate, a will. [The doctrine] comes into play only after a will is found to be valid."59 One might question the logic of a jurisdiction's willingness to engage the tough questions on constructional levels-as through presumptions against intestacy and careful location of intent-but not operational levels, the very foundation of the testamentary exercise. ${ }^{60}$

55. See, e.g., Thompkins v. Randall, 150 S.E. 249, 251 (Va. 1929) (favoring heirs when testamentary intent was unclear).

56. Consider a trio of Oklahoma statutes: "Of two modes of interpreting a will, that is to be preferred which will prevent a total intestacy.” OKLA. STAT. ANN. tit. 84, § 160 (West 2003). "In case of uncertainty, arising upon the face of a will, as to the application of any of its provisions, the testator's intention is to be ascertained from the words of the will, taking into view the circumstances under which it was made, exclusive of his oral declarations." Id. § 152 . "Several testamentary instruments, executed by the same testator, are to be taken and construed together as one instrument.” Id. § 154 . Combined, the statutes seem to favor testate succession-and, thus, testamentary intent-over intestacy, permit non-documentary evidence to locate it, and support the validation and integration of multiple documents of questionable compliance and intent into a single testamentary instrument bearing both.

But case law forecloses the argument. For example, section 154 raises the interesting question of whether the term "testamentary instrument" means "validly executed," such that two noncompliant documents could not be integrated into a single, compliant one. On one hand, the answer seems to be yes, as per the court's admonition in In re Paull's Estate that section 154 "deals with the interpretation of wills," and thus is inapplicable unless a will is initially found. 254 P.2d 357, 359 (Okla. 1950). As a later case reinforces, "an instrument which is not a will does not become one until executed as required by law.” Hooker v. Barton, 284 P.2d 708, 710 (Okla. 1955). Nevertheless, the Oklahoma Supreme Court's liberal construction of a will as essentially anything "testamentary in character" suggests that section 154, in using the phrase "testamentary instrument" rather than the word "will," is even more clearly applicable to any instrument with a testamentary flair. Johnson v. Johnson, 279 P.2d 928, 930 (Okla. 1954) (per curiam). This paves the path for many noncompliant documents reflecting varying degrees of testamentary intent to be read together as a single, compliant one.

57. 528 A.2d 918, 920 (N.J. 1987).

58. Id. at 922 .

59. Id. (emphasis added) (citations omitted).

60. Cf. In re Estate of Williams, 66 Cal. Rptr. 3d 34, 49 (Cal. Ct. App. 2007) (“Such prior declarations of intent to make a will are admissible when the attempt is not to explain an ambiguity but to show the testamentary character of a letter.”). 
As with effecting a valid will, revoking one also requires intent, this time revocatory, plus a sufficient act. ${ }^{61}$ Such acts include express or implied revocation through the execution of a later will, or engaging in certain conduct, such as "burning, tearing, canceling, obliterating, or destroying" the former instrument. ${ }^{62}$ Where direct and, indeed, written evidence of testamentary intent does not exist, neither will the will itself. But where direct evidence of revocatory intent does not exist, courts ease evidentiary burdens by indulging its presumption for a will known to have been in the testator's possession before death and either not found or found mutilated thereafter. ${ }^{63}$ No witnesses are necessary to raise the presumption, and the type and level of proof required to rebut it will vary. ${ }^{64}$

\section{THE ELUSIVENESS OF TESTAMENTARY INTENT}

Anything that has become so undeniably central to a will and sure to only grow in relevance as technologies expand should be capable of clear explication on both definitional and doctrinal levels. For testamentary intent, this is not the case. Moreover, even where answers arguably exist, they are not always as sound as they could be. That an answer is clear does not mean it is good, and discordant policy merely exacerbates the lack of clarity.

\section{A. Testamentary Intent Defined}

The courts have said again and again that the test whether or not an instrument is testamentary... is whether it was executed with... testamentary intent. While this is a standard form of orthodox statement, it is in itself of little help since it does not explain what... testamentary intent is. ${ }^{65}$

How peculiar to require the indefinable. State statutes rarely define testamentary intent. Instead, if they speak of it at all, they merely imply its requisite nature by assigning to contestants the burden to prove its absence $^{66}$ or directing the sources from which it can be drawn. ${ }^{67}$ As

\footnotetext{
61. See Unif. Probate Code § 2-507(a) (amended 2008), 8 U.L.A. 151 (1998).

62. Id.

63. See, e.g., Evans v. May, 923 S.W.2d 712, 714 (Tex. App. 1996) (stating the rule).

64. See id.

65. 1 PAGE, supra note 20, § 5.6 (footnote omitted).

66. The Alaska Statute is representative, particularly of jurisdictions having adopted the
} 
candidly recognized by the Montana courts, judicial pronouncement must fill this legislative vacuum: "There is no definite fixed rule for determining testamentary intent, [and] each case must stand on its own peculiar facts and circumstances."68 Notwithstanding the merits and demerits of flexibility, its overlay atop already indeterminate legal precepts results in unnecessary disarray. What is more, to the extent that precedent functionally creates and entrenches both definition and doctrine, the foregoing statement is possibly untrue.

Perhaps "false security [inheres in] precise definitions," 69 especially given the correlative truism that "[t]here 'is no magic in the words themselves.",70 Moreover, the subjectivity of any intent, testamentary or otherwise, often makes its evidentiary capture difficult to achieve. As can be stated more generally of the holographic will itself, imprecision may be unavoidable yet desirable whenever law and life intersect so vividly. Nevertheless, a second more critical casualty of definitional amorphism is comprehension of the fundamentals that the words try to define. As such, imprecise and short-handed wordplay hinders both precision and understanding. Circularity is unmistakable when testamentary intent is equated with animus testandi and cast roughly as the "intent to make a will," 71 but the definition of a "will" is either

Uniform Probate Code: "Contestants of a will have the burden of establishing lack of testamentary intent or capacity, undue influence, fraud, duress, mistake or revocation.” ALASKA STAT. ANN. $\S 13.16 .170$ (West 2007) (emphasis added). In other jurisdictions, testamentary intent may be a component of the factum of the will, to be established or averred by its proponent in the course of admission to probate. See In re Will of Smith, 528 A.2d 918, 920 (N.J. 1987) (in denying probate to a letter written by the decedent to her attorney, the court noted that "[a]lthough the statute does not allude to it, testamentary intent has always been a prerequisite to admission of an instrument to probate").

67. See, e.g., N.D. CENT. CODE ANN. § 30.1-08-02(3) (West 2008) ("Intent that the document constitute the testator's will can be established by extrinsic evidence, including, for holographic wills, portions of the document that are not in the testator's handwriting.").

68. In re Estate of Johnson, 60 P.3d 1014, 1017 (Mont. 2002) (citing In re Augestad's Estate, 106 P.2d 1087, 1088 (Mont. 1940)).

69. THOMAs E. ATKINSON, HANDBOOK OF THE LAW OF Wills AND OTHER PRINCIPLES OF SuCCESSION INCLUDING INTESTACy AND AdMinistration OF DECEDENTS' Estates 2 (2d ed. 1953).

70. 1 PAGE, supra note 20, $\S 1.5$ (footnote omitted) (discussing early real versus personal property distinctions in the terms "will" and "testament”).

71. See, e.g., Edmundson v. Estate of Fountain, 189 S.W.3d 427, 430 (Ark. 2004) (noting a document was found defective for "lack[ing] the required animus testandi or intent to make a will”); In re Kemp's Will, 186 A. 890, 894 (Del. Super. Ct. 1936) (“Animus testandi is the intention or serious purpose to make a will.”); Kidd v. Gunter, 551 S.E.2d 646, 648 (Va. 2001) (““[T]here must be a concurrence of the animus testandi and the animus signandi-that is, the intention to make a will and the intention to sign the instrument as and for a will.'” (quoting Hamlet v. Hamlet, 32 S.E.2d 729, 732 (Va. 1945))); In re Estate of Teubert, 298 S.E.2d 456, 461 (W. Va. 1982) (noting 
tautological as an expression of or document written with testamentary intent $^{72}$, facile, ${ }^{73}$ or capable of broad variance. Non-definitional "definitions" hurt more than they help.

Usage of the word "will," so critical to many formulations of testamentary intent, is independently susceptible to numerous and even conflicting meanings ${ }^{74}$ ranging between verb and noun, inquiry and assurance, and desire and document. ${ }^{75}$ Even when limited to use as a noun, that the word continues this definitional spectrum on content, expressive, and intent levels can confound one's search for either its meaning or the intent to make it.

\section{Content Variance}

While one’s generic “will” may broadly express wishes about any subject in the world, ${ }^{76}$ only two categories compete in attempting a

that "there are some dispositive words demonstrating an intent to make a will ... which indicate, to some extent, testamentary intent”); see also Langbein, Substantial Compliance, supra note 34, at 491 (observing that "[the assorted wills doctrines] are directed to two broad issues of testamentary intent[, the first being whether] the decedent intend[ed] to make a will”).

72. See, e.g., GA. CODE ANN. § 53-1-2(17) (West 2011) (“'Will’ means the legal declaration of an individual's testamentary intention regarding that individual's property or other matters.”); S.D. CODIFIED LAWS § 29A-1-201(52) (2004) (“'Will’ means an instrument, including a codicil, executed with testamentary intent and in the manner prescribed by this code....); In re Daniel J. Rosenbaum Trust, No. 81213, 2003 WL 1849141, at *2 (Ohio Ct. App. Apr. 10, 2003) (“Although there is no specific statutory definition of a 'will,' case law and statutes make it clear that 'a will must be in writing, executed with certain formalities and by its language demonstrate, at the minimum, a testamentary intent, i.e., a disposition of property to take effect only at death."” (quoting In re Estate of Ike, 454 N.E.2d 577, 579 (Ohio Ct. App. 1982))).

73. Some statutory definitions of the will essentially observe that it stands for a last will and testament or includes the word “codicil.” See, e.g., DEL. CODE ANN. tit. 1, § 302(22) (West 2006) (defining will as a last will and testament including a codicil); MISS. CoDE ANN. § 1-3-59 (West 1999) (noting that the term "will" includes codicils); N.J. STAT. ANN. § 3B:1-2 (West 2007) (defining will as a last will and testament and including codicils).

74. See, e.g., MERRIAM-WEBSTER's COLLEGIATE DiCTIONARY 1354 (10th ed. 1997) (reflecting such disparate notions as "desire, choice, willingness, consent, ... refusal"; "habitual action or natural tendency or disposition"; "futurity"; "capability or sufficiency"; "probability”; “determination, insistence, persistence, or willfulness”; “inevitability”; “command, exhortation, or injunction”).

75. For example, as a verb, it can connote wish or intent that may never happen, or it can indicate the declarant's belief or even warrant that something is certain to occur. Id. Both usages suggest futurity; one suggests but cannot promise inevitability. Compare "I will-action, formed and deliberate intent; outcome unclear but within declarant's control_fairly exercise my choice, will_ action, interrogative, outcome unclear-she?” Moreover, it can also be used as a generic synonym for the verbs "bequeath" or "devise," which may mean that some act-although lacking ultimate effect-has already occurred: "I have willed — completed but revocable action based on intent-my real property to my brother and my personal property to my sister."

76. For example: "It is my will-current desire-that she should listen to me." 
workable definition of testamentary intent: content-broad desire related to some consequence of death ${ }^{77}$ or a content-narrow direction requiring the actual deathtime disposition of property. ${ }^{78}$ The second definition is initially more intuitive than the first, in that people justifiably think of

77. Early sources illustrate this. Blackstone defines the will as "'the legal declaration of a man's intention which he wills to be performed after his death.”' 2 WiLliam BLACKSTONE, COMMENTARIES ON THE LAWS OF ENGLAND 499-500 (1768). In like vein, Henry Swinburne states that "[a] Last Will is a lawful disposition of that which any would have done after Death." HENRY SWinBurne, A TREatise of Testaments AND LASt Wills 12 (5th ed. 1728). Whether Swinburne's term "lawful disposition" means legal, not unlawful, or legally effectuated, statutorily compliant, it seems that both definitions would encompass documents containing no property disposition at all, and they could also ostensibly embrace such non-testamentary transactions as death-conditional deeds. Indeed, it is on the latter point that objection to the definition has been raised. ATKINSON, supra note 69, at 2. Traditionalists would argue that by definition, "will substitutes" are not wills, but rather their inter vivos approximations. Thus, intent to create them could not be deemed "testamentary intent" for purposes of admitting such a document to probate. Given the proliferation of will substitutes after Professor Atkinson wrote his treatise in 1953, such a broad definition of testamentary intent could have ranging effect, particularly where the intent to create the will substitute was not matched with the formalities through which to accomplish it. On the rise of the will substitute generally, see John H. Langbein, The Nonprobate Revolution and the Future of the Law of Succession, 97 HARV. L. REV. 1108 (1984).

An Oklahoma court discussing the applicability of a will doctrine to a revocable trust echoes the concern:

[T]o [incorporate assorted deathtime transfers into the will] "would mean that joint tenancy deeds, joint bank accounts, bonds payable on death to another, and similar instruments, would constitute the 'will' of [a] decedent and would have to be admitted to probate. It is clear that such documents are not a part of the probate estate and are not a part of a decedent's will."

Miller v. First Nat'l Bank \& Trust Co., 637 P.2d 75, 78 (Okla. 1981) (Hargrave, J., dissenting) (third alteration in original) (quoting In re Estate of Meskimen, 235 N.E.2d 619, 623 (Ill. 1968)).

78. This definition is commonly stated, even if not commonly applied. 1 THOMAS JARMAN, A TREATISE ON WILLS 29 (7th ed. 1930) (““A will,' . . ' 'is an instrument by which a person makes a disposition of his property to take effect after his decease, and which is in its own nature ambulatory and revocable during his life.” (citations omitted)); 4 JAMES KENT, COMMENTARIES ON AMERICAN LAW 555 (7th ed. 1851) ("A will is a disposition of real and personal property to take effect after the death of the testator."). Although often in derogation of or preceding relevant statute, many cases accord. See Twilley v. Durkee, 211 P. 668, 673 (Colo. 1923) ("[U]nder our statute, unless it disposes of property, [a written instrument] to take effect at the testator's death, is not a will ....”); Mallory v. Mallory, 862 S.W.2d 879, 881 (Ky. 1993) ("[E]xpression of testamentary intent... require[s] 1) a disposing of property 2) which takes effect after death.” (citing Simon v. Wildt, 84 Ky. 157 (1886))); Succession of White, 961 So. 2d 439, 441 (La. Ct. App. 2007) (“To be a valid ... will, a document must meet the requisites of form and contain testamentary intent, which is to say, 'it must, by its own language, show on its face that it purports to dispose of the property of the testator on his death.”' (quoting Succession of Shows, 158 So. 2d 293, 295 (La. Ct. App. 1963))); In re Estate of Blackburn, 253 S.W.3d 603, 615 (Tenn. Ct. App. 2007) ("In assessing testamentary intent, '[the testator's legal understanding is immaterial] so long as the document demonstrates... clear intention to dispose of . . property after . . . death.'” (quoting In re Meade, 156 S.W.3d 841, 843-44 (Tenn. Ct. App. 2004))); In re Estate of Allen, 301 S.W.3d 923, 927 (Tex. App. 2009) (noting that testamentary intent depends on the maker's intention to create an irrevocable disposition of property). 
wills as vehicles through which to transmit their estates. ${ }^{79}$ But as wills often do much more than that, this common but narrowly drawn definition could cut many estate-related documents out of the will label and, thus, fail to reflect the requisite intent to make one.

For example, consider an unambiguous and validly attested document revoking all prior wills, naming a personal representative for the estate and a guardian for minor children, suggesting an attorney, disinheriting all descendants, clarifying the identity of the current spouse, but failing to dispose of any property. In jurisdictions following the more narrow definition, the document could not itself be a will and, therefore, could not (1) integrate any other pages present at its execution and intended for inclusion; (2) incorporate any other document by reference; (3) republish any earlier will by codicil, with potential downstream effects on subsidiary doctrines such as interested-witnesses analysis; (4) support its own subsequent codicil; (5) discharge the obligations of a statute demanding disinheritance of descendants to be clear on a will's face; or perhaps most shockingly, (6) accomplish its revocatory intent in a jurisdiction limiting revocation to physical act or subsequent will. The net result of such "non-will” status treats it as but a precatory expression of intent, which renders it inadmissible to probate and binding on none. ${ }^{80}$

With varying corrective, most state statutes recognize the shortcomings of a purely disposition-based definition and lean toward the first option above. Compare, for example, a limited definition of a will that excludes merely revocatory documents and assumes that no instrument is "testamentary" unless making a positive disposition of property upon death ${ }^{81}$ with an expansive definition that embraces "any

79. This predilection toward wills as positive, dispositive acts is reflected in the lingering majority rule refusing to effectuate so-called "negative wills" that deny rather than grant beneficiary status. See, e.g., In re Estate of Baxter, 827 P.2d 184, 186-87 (Okla. Civ. App. 1992) (“[A] testator cannot disinherit his heirs by words alone, but in order to do so, the property must be given to somebody else.”).

80. See generally 1 PAGE, supra note 20, $§ 1.5$ (discussing legal effect of definitions of wills and testaments on realty and personalty). A few arguments might be tried. For example, when a testator limits an heirship or revokes a will, property implicitly transfers to others-prior will beneficiaries upon revival, other heirs if not. Moreover, if the jurisdiction nominally transfers ownership to executors pending final estate distribution, designating or changing that individual may suffice as property disposition to maneuver the statute. Finally, the jurisdiction could determine that while not a "will," the document's compliance with testamentary formalities permits incorporation or republication of documents with their own dispositive provisions so as to fulfill the definitional requirement. But these possibilities are not given and, either way, could engender wasteful litigation in asserting them.

81. See In re Estate of Gushwa, 197 P.3d 1, 3-5 (N.M. 2008). 
instrument, including any codicil or other testamentary instrument... [that] disposes of personal or real property, appoints a personal representative, conservator, guardian, or trustee, revokes or revises an earlier executed testamentary instrument, or encompasses any one or more of such objects or purposes."82 Ironically, if the disposition-based view is too narrow, the alternative may be too broad.

\section{Expressive Variance}

Will definitions also differ over the format within which a document must be expressed, ${ }^{83}$ encompassing either a format-intermediate written expression of desire ${ }^{84}$ or a format-narrow and statutorily compliant written expression of desire. ${ }^{85}$ The first definition recognizes the difference between an invalid will and a valid one. Under the second, the phrase "valid will" is redundant, and "invalid will" is oxymoronic.

For example, consider the breadth of the statement that "an instrument may be too defective to be entitled to probate but if it is testamentary in character it is a will." ${ }^{\text {,6 }}$ Such expansive language ignores formalities as long as the relevant document exists. Moreover, all will

82. NEB. REV. STAT. § 30-2209(53) (2009). One might elude this difficulty if it is true that "[i]nstruments which have been intended to have testamentary effect have been considered to be wills though they make no effective disposition of property.” ATKINSON, supra note 69, at 3; see also RESTATEMENT (THIRD) OF PROP.: Wills \& OTHER DONATIVE TRANSFERS § 3.1 cmt. a (1999) (broadly defining a will); L.S.T., Annotation, Character of Instrument as Will, or Its Admissibility to Probate as Such, as Affected by Its Failure to Make Any Disposition of Property or by Fact that There Is No Beneficiary Entitled to Take Thereunder, 147 A.L.R. 636 (1943) (discussing whether instruments that do not dispose of any property are wills or are admissible to probate).

83. Oral wills require no document, but are so limited and rare as to not require additional discussion. Case law, however, occasionally loosens the tie with inarticulate language. See, e.g., Miller v. First Nat'l Bank \& Trust Co., 637 P.2d 75, 77 (Okla. 1981) (“A will is a declaration of what a person desires to be done after death. It is revocable during one's lifetime, inoperative until death, and applicable to the situation that exists at the time of death." (footnote omitted)).

84. See, e.g., id. (stating that "an instrument may be too defective to be entitled to probate but if it is testamentary in character it is a will”); see also Johnson v. Johnson, 279 P.2d 928, 930 (Okla. 1954) (per curiam) (same); Loveren v. Eaton, 113 A. 206, 207 (N.H. 1921) (stating that a will is "the instrument by which [one] expresses his intentions as to the disposition of his property at his death" and further noting that where codicil is valid, it is "immaterial" whether earlier testamentary paper complied with formalities).

85. This approach is implicitly taken by courts refusing to apply will-construction statutes to a document not yet determined to be one. See, e.g., In re Will of Smith, 528 A.2d 918, 922 (N.J. 1987) (noting that the doctrine of probable intent is only available to interpret, not validate a will); see also supra note 56 and accompanying text.

86. Miller, 637 P.2d at 77 (footnote omitted). 
substitutes could be subject to a host of subsidiary will doctrines, such as revocation by divorce, ademption by satisfaction, and lapse. ${ }^{87}$

\section{Perception Variance}

Finally, will definitions differ over the nature and extent of their writer's perspective on the content of the writings: any expression of testamentary desire, expression through a document that its maker intends as the actuating instrument, ${ }^{88}$ or expression through a document that its maker perceives as a "will." 89

If testamentary intent equals the "intent to make a will," and if these assorted permutations could leave one wondering what a will even is, then the same question holds true for testamentary intent. Is a will a desire about dispositions or about documents? Reifying the answer produces several potential options for what the will expresses: (1) the underlying desire merely evidenced by the document-the will is a desire; (2) the physical piece of paper expressing that desire - the will is a document; (3) a specific assemblage of the words written thereon-the

87. But see Pepper v. Peacher, 742 P.2d 21, 24 (Okla. 1987) (noting that while the argument that divorce revoked an ex-spouse's beneficiary designation under a retirement plan "possesses merit" given prior Oklahoma definition of a will, such definitions were contextually rejected as unacceptably stretching its meaning as applied to a revocation-upon-divorce statute). Peacher did not, however, overrule any prior cases. Therefore, it may be simply a matter of time before the broad definition is again invoked under slightly different facts.

88. See, e.g., Wiggins v. Wiggins, 2 So. 2d 402, 403 (Ala. 1941) (noting that animus testandi must exist at execution and must apply to the particular instrument proffered as the will); In re Estate of Kimble, 871 P.2d 22, 25 (N.M. Ct. App. 1994) (holding that while testamentary intent does not depend on its maker's understanding of the legal effect of the document, it does require the intent that the very paper in question effects the disposition sought); In re Taylor's Will, 17 S.E.2d 654, 655 (N.C. 1941) ("The animus testandi required is more than an intent to execute a will. It is the intent to presently devise by the paper writing being then executed and that such writing shall have the full force and effect of a will. ... It must appear from the language used that it was the writer's intent that the paper itself should operate as a disposition of her property to take effect after death." (citations omitted)). See also infra note 92 and accompanying text.

89. Professor Page states that "[i]n some cases it has been said, in obiter, that the instrument is not a valid will unless the testator knows that it is, in the eyes of the law, a will and intends it to have this effect.” 1 PAGE, supra note 20, § 5.6. He continues, however, by observing that the decisions do not seem to turn on the issue-yet recognizing its implicit hold where publication is requiredand concludes by agreeing that most courts do, however, require that the testator imbue the precise instrument with testamentary significance. Id.

Dicta or not, the distinctions may often be lost in translation, particularly where the term "testamentary intent” is conflated with "intent to make a will.” See, e.g., In re Estate of Smith, 528 A.2d 918, 922 (N.J. 1987) ("[T]he issue is not whether the writing probably expresses [the decedent's] intention concerning the disposition of her estate if it were testamentary in character, but whether she intended that writing to be her will." (emphasis added)). 
will is the part of the document that expresses desire. While the three may usually coalesce, the issue is not academic. For example, a jurisdiction could require an entirely handwritten holographic will or that signers placed their marks at the end of an attested will. If statutory compliance proves testamentary intent, each instance invites exploration of what constitutes the actual "will" so as to permit it to meet these physically oriented requirements. Inversely, if true testamentary intent always generates statutory compliance, one may view a putative testator's arguable non-compliance as evidence that it wavers or possibly does not exist. ${ }^{90}$ As one's very understanding of the definition of a will might effect inadvertent rule-breaking, the consequence of testamentary intent triples: testamentary intent holds stand-alone importance as half or more of the equation of a valid will and affects a finding of formality compliance - the other half or less-which itself creates presumptions about its existence.

Few courts overtly struggle with the contours of testamentary intent, leaving much of the jurisprudential burden either on factual shoulders or negative implications - what testamentary intent is not, rather than what it is. ${ }^{91}$ Notwithstanding these difficulties, it essentially distills into two sub-components with the first more easily intuited than the second. Testamentary intent is the intent to (1) effect a deathtime disposition of property through (2) the specific document proffered. ${ }^{92}$ As explored in

90. Such discussion suggests strict compliance review.

91. For example, testamentary intent is not: the present intent to make a present transfer; the present confirmation of a previous actual or perceived transfer, see, e.g., Barnes v. Viering, 206 A.2d 112, 113 \& n.1 (Conn. 1964) (letter suggested no need to make a will as letter recipient "knew" that property "really belong[ed] to [him]"); intent to make an irrevocable gift, see, e.g., Mallory v. Mallory, 862 S.W.2d 879, 881 (Ky. 1993); past or future intent to convey, see, e.g., Boggess v. McGaughey, 207 S.W.2d 766, 767 (Ky. 1948) ("There must be a contemporaneous intention thereby to create a revocable gift of property to take effect at death, and not merely to declare a purpose to make a gift in praesenti or . . . to speak of such action as already done....”)); a guideline for an executor or attorney, see, e.g., Succession of Carroll, 30 So. 3d 11, 17-18 (La. Ct. App. 2009) ("'[The document was] to be used only if legally necessary. It [was] just a guideline if not necessary.”’); an inventory of assets, id.; or a will substitute.

92. Gulliver and Tilson note that "[d]ispositive effect should not be given to statements which were not intended to have that effect.” Gulliver \& Tilson, supra note 34, at 4 . The assertion leads to the view that no document reflecting testamentary intent should be effective as a will unless its creator imbued it with that level of significance. The leading treatises agree, and case law generally follows suit. See, e.g., GERRY W. BEYER, WILls, Trusts, AND ESTATES: EXAMPLES AND EXPLANATIONS $§ 5.3$ (1999) ("The testator must intend that the very instrument the testator executed will serve as the testator's will; that is, the document that states the testamentary desires to be effective upon death.”); 1 PAGE, supra note 20, $\$ 5.14$ ("Most states have the rule that in order for an instrument to constitute a testamentary disposition, it must show the testator's intention to make a testamentary gift by 'that very instrument[] or paper itself . . . .”'). See also Boggess, 207 S.W.2d at 767 (characterizing as "indispensable" that at execution, the paper was designed to make a 
Part III, the statement's simplicity masks numerous subtleties, which may explain why testamentary intent seems less cogently developed than its import would warrant.

\section{B. Testamentary Intent Established}

The problem of whether a letter discloses testamentary intent is a difficult and elusive one and it is hard to reconcile all the cases or even to classify them. ${ }^{93}$

It is remarkable that no single rule has emerged identifying the appropriate sources from which testamentary intent may be drawn, given its consequence to compliant and noncompliant documents alike. While the cases evade precise categorization, three approaches emerge: (1) the proffered document itself must reflect it; ${ }^{94}$ (2) extrinsic evidence may establish it if the proffered document is ambiguous; ${ }^{95}$ and (3) extrinsic

testamentary disposition); Succession of Rhodes, 899 So. 2d 658, 660 (La. Ct. App. 2005) (requiring that decedents have intended the very paper offered to be the will); In re Estate of Allen, 301 S.W.3d 923, 928 (Tex. App. 2009) ("There must be evidence that the testator intended that the very document at issue be the instrument that actually makes the disposition of the testator's property.”); Thompkins v. Randall, 150 S.E. 249, 251 (Va. 1929) ("Testamentary intent... means that the writing offered for probate must have been executed by the testator with the intent that such writing take effect as his last will.”); Restatement (ThiRD) OF Prop.: Wills \& OTHER Donative TRANSFERS $\S 3.1 \mathrm{cmt}$. g (1999) ("To be a will, the document must be executed by the decedent with testamentary intent, i.e., the decedent must intend the document to be a will or to become operative at the decedent's death.”).

93. AtKinson, supra note 69, at 210.

94. See, e.g., Barnes, 206 A.2d at 113-14 (determining that the will's language must "in and of itself" express testamentary intent without the use of any extrinsic evidence); Mallory, 862 S.W.2d at 882 (reversing lower court rulings that handwritten, dated, and signed "by my hand" document found in Bible sufficiently expressed testamentary intent, in part by refusing to consider that decedent had told proponent "to look in the Bible" and that putative heirs had visited decedent perhaps twice in preceding decade); Succession of Carroll, 30 So. 3d at 17 (rejecting extrinsic, parol evidence to establish testamentary intent in asset inventory or attorney instructions); Wolfe v. Wolfe, 448 S.E.2d 408, 409 (Va. 1994) (examining a signed and dated letter addressed to executor of prior will stating "I want my daughters to share $1 / 3,1 / 3,1 / 3$ " and finding it devoid of testamentary intent, which must be "determined by looking at the document itself," notwithstanding decedent's suicide attempt on same day of letter and success fifteen days later).

95. See, e.g., In re Estate of Webber, 551 P.2d 1339, 1341-43 (Idaho 1976) (admitting extrinsic evidence to discern whether testamentary intent existed within card bearing allegedly ambiguous statement "I bid this world goodbye[, and] I leave my land to you"); In re Estate of Duemeland, 528 N.W.2d 369, 370-71 (N.D. 1995) (responding to contestant's assertion that testator did not truly intend disinheriting effect of duly attested will, court noted that "[absent] ambiguity, extrinsic evidence is not admissible except to show fraud or mistake"); In re Estate of Moore, 277 A.2d 825, 826-27 (Pa. 1971) (finding no testamentary intent in direction letter to attorney and noting that extrinsic evidence admissible on point only where "real doubt or real ambiguity" exists); In re Estate of Hendler, 316 S.W.3d 703, 708 (Tex. App. 2010) (permitting consideration of surrounding facts and circumstances if testamentary intent is unclear from instrument language). 
evidence may establish it whether the proffered document is ambiguous or not. ${ }^{96}$

The absence of a consistent rule is disappointing for the inattention to and devaluation of testamentary intent that it suggests. It also hinders outcome prediction, particularly where choice-of-law issues arise or ancillary probate introduces another state's law into core distributional matters. ${ }^{97}$ While property law historically reflects jurisdictional differences, these differences retard comprehensive theoretical analysis and encourage litigation. ${ }^{98}$ Cross-jurisdictional disagreement, though discouraging, may pale against the internal disarray manifest within a single jurisdiction, case, or court. The simultaneously procedural and substantive gatekeeping role that ambiguity plays levies intense pressure against the expressive clarity of the document to the detriment of analyzing the decedent's actual intent. And any rule that impedesmuch less bars - a search for testamentary intent acts counterintuitively given its importance to the instant question, as well as to broader political, philosophical, and sociocultural theory. ${ }^{99}$

Jurisdictions squarely rejecting extrinsic evidence of testamentary intent usually also require the document's writer to intend the testamentary effect of the particular instrument itself, which functionally adds an additional but covert formality rule to the extant ones. ${ }^{100}$ This

96. The Restatement view is that testamentary intent is a question of fact-thus not susceptible to summary judgment-and need not be shown from the face of the will, but can be inferred from the document or established by extrinsic evidence. RESTATEMENT (THIRD) OF PROP.: WiLLS \& OTHER DONATIVE TRANSFERs $\S \S 3.1 \mathrm{cmt}$. g, $3.2 \mathrm{cmt}$. c (1999). This forgiving approach, also adopted by the Uniform Probate Code in section 2-502, 8 U.L.A. 144, predominates when the question is statutorily resolved. See, e.g., N.J. STAT. ANN. § 3B:3-2(c) (West 2007) (substituting “writings intended as wills” for holographic wills); S.D. CoDIFIED LAWS § 29A-2-502(c) (2004) (allowing the establishment of testamentary intent by extrinsic evidence, "including, for holographic wills, portions . . . that are not in the testator's handwriting”); In re Estate of Serbousek, 751 N.W.2d 718, 722 (S.D. 2008) (reversing and remanding on grounds that lower court failed to consider extrinsic evidence bearing upon decedent's intent in handwriting note and placing it in her pillow).

97. Cf. In re Last Will \& Testament of Palecki, 920 A.2d 413, 421-27 (Del. Ch. 2007) (finding that although decedent resided in a harmless-error jurisdiction when executing her alleged unsigned codicil to a valid holographic will, her domicile at death, notwithstanding choice-of-law rules promoting testate succession, could not effectuate the document consistent with internal rules); Lawrence H. Averill, Jr., An Eclectic History and Analysis of the 1990 Uniform Probate Code, 55 ALB. L. REV. 891, 895 (1992) (noting that in addition to unjust results, non-uniformity may generate “confusion and distrust among a very mobile lay populace”).

98. While interjurisdictional differences might encourage critique given competing views and theories from which to draw, the difficulty would be separating "pervasive objective policy" from “mere subjective result.” Averill, supra note 97, at 911 (citing John T. Gombatz, Notes Toward a Truly Modern Wills Act, 31 U. MiAmi L. REV. 497, 542 (1977)).

99. See infra Part V.A.

100. See, e.g., Edmundson v. Estate of Fountain, 189 S.W.3d 427, 430 (Ark. 2004). 
calls to mind the derided formalistic view that one really intends a will only upon complying with all formalities-creating a conclusive presumption of intent - or inversely, that failure to meet all formalities reveals that one did not truly intend a will-allowing a conclusive presumption of no intent. The syllogism is flawed. First, the only appropriately drawn "conclusion" is that a court may deny probate to a noncompliant document. Second, recall that statutory compliance does not conclusively establish testamentary intent anyway. It is telling to position this three-way split for admitting extrinsic evidence to prove testamentary intent against the single majority rule that accepts it to disprove the intent driving documents regular on their face. ${ }^{101}$

Tautologically, determining the admissibility of extrinsic evidence to prove testamentary intent raises questions over both the appropriate distinction between "intrinsic" and "extrinsic" evidence and the definition of a "will." 102 Inter- and intra-jurisdictional difference on all scores hampers cognizability and permits the cynical supposition that determinations are fluid depending on the contextual framework, particularly where the same court or jurisdiction deploys alternate definitions or spins precedent in ways that harden or soften its edge. For testamentary intent to retain or even expand its superiority within wills jurisprudence, then the law should cogently define and consistently seek it.

\section{Elusiveness Compounded: Coupling Definition and Proof}

The number of cases involving testamentary intent discourages systematic attempts to classify facts, laws, and outcomes. That said, every appellate decision reveals at least one positional split fairly representative of those that propel litigation generally. Three jurisdictions illustrate the disservice that definitional imprecision,

101. See supra notes 19-20 and accompanying text (discussing compliance-intent interplay and the "sham will").

102. For example, how broadly a will is defined may affect whether evidence of intent is intrinsic or extrinsic thereto. See, e.g., In re Estate of Foxley, 575 N.W.2d 150, 152-55 (Neb. 1998) (reversing two lower court opinions that considered typed portions of a purported holographic will to establish the requisite intent); see also UNIF. PROBATE CODE § 2-502(c) (amended 2008), 8 U.L.A. 145 (1998) (providing that typed portions may establish intent of holographic wills). A jurisdiction that only requires the material provisions or portions of a holographic will to be in the testator's handwriting implicitly, at least for this purpose, defines the will as the entire paper itself rather than merely the handwritten words. 
evidentiary disagreement, and their combined effects hold for testamentary intent.

\section{Oklahoma: Diffuse Definitions and Evidentiary Ambiguity}

Oklahoma law seems straightforward enough: a valid will is a written and statutorily compliant instrument that disposes of property on death and is both "ambulatory and revocable during the testator's lifetime."103 Things are less clear than they initially seem.

The Oklahoma Supreme Court has often asserted its "commit[ment] to the rule that ... '[w]here an instrument is tendered for probate as an holographic will, [testamentary intent] must be plainly apparent.",104 Ironically, the court itself fails to be either plain or apparent in its pronouncement by leaving unanswered whether that "plain appearance" may be discerned from extrinsic sources or must derive from the document under review.

While an early Oklahoma case intimates that the intrinsic approach controls by requiring that the will's provisions along with its identity be determined from the instrument itself, ${ }^{105}$ no statutory ${ }^{106}$ or case law has ever specifically so provided. Indeed, the Oklahoma Supreme Court has elsewhere stated that "[i]n determining whether or not an instrument offered for probate constitutes a holographic will, the court will consider all of the facts and circumstances surrounding its execution ... to arrive at the true intent of the testator."107 Casting the net so broadlyirrespective of an initial finding of documentary ambiguity-arguably includes anything of relevance, such as the decedent's relationship with putative beneficiaries and presumptive heirs, the decedent's health and the presence of exigent circumstances in testamentary attempts, the decedent's familiarity with appropriate will forms, the subsequent conduct and statements of the parties, and the delivery or retention of the subject writing.

103. In re Estate of Worsham, 859 P.2d 1134, 1135-36 (Okla. Civ. App. 1993) (citing In re Estate of Baxter, 798 P.2d 644, 646 (Okla. Civ. App. 1990)).

104. Craig v. McVey, 195 P.2d 753, 754 (Okla. 1948) (quoting In re Young's Estate, 219 P. 100, 100 (Okla. 1923)); see also Hooker v. Barton, 284 P.2d 708, 708, 710 (Okla. 1955).

105. Day v. Williams, 85 P.2d 306, 308 (Okla. 1938).

106. Statutes that initially seem to resolve the issue turn out to be false leads. See supra Part II.B.2.

107. In re Paull’s Estate, 254 P.2d 357, 361 (Okla. 1950). 
In other testamentary contexts, Oklahoma courts have either candidly sidestepped identifying the sources from which intent may be drawn or explicitly required that certain evidence appear on the document's face. ${ }^{108}$ Such tactics either communicate that extrinsic evidence is admissible absent specific contrary directive or assume that the "plainly apparent” rule provides sufficient clarity regarding primary testamentary intent. Both interpretations are possible; neither is clear. Moreover, the case law in Oklahoma exhibits the attendant difficulties when the law of more than one jurisdiction arguably applies. Indeed, the existence of a conflicting choice-of-law question could create the latent ambiguity for which the admission of extrinsic evidence has traditionally been an appropriate corrective. ${ }^{109}$

Case review reveals the predictive difficulty attending the intent inquiry, notwithstanding the court's magnanimous but common rejection of the need for formality or technical words. ${ }^{110}$ The distinctions drawn will often turn less on the documentary language used than on the serendipity of discoverable evidence beyond the decedent's control, such as the time lapse between the document's creation and the decedent's death or the writer's statements to others about having made a will. Compare whether testamentary intent exists more clearly in the statement "[i]nasmuch as I do not have a will, I would like to make the following arrangements in the event of my death"111_ itself acknowledging that its writer did not believe the letter to be a will-than in the following phrases where the documents were rejected: "when I die I want you to

108. See, e.g., In re Estate of Severns, 650 P.2d 854, 857 (Okla. 1982) (requiring "strong and convincing language" on the will's face that decedent's will intentionally omitted children and rejecting extrinsic evidence where will is silent on point); Estate of Crump v. Freeman, 614 P.2d 1096, 1098 (Okla. 1980) ("The pretermitted-heir statute superimposes itself upon the silent will . .. . The status once so created by force of law cannot be erased by parol. The needed intent for the heir's omission cannot come dehors the will from sources not testamentary in character." (footnote omitted)); In re Abrams' Will, 77 P.2d 101, 103 (Okla. 1938) ("The omission of the date from the will cannot be supplied by [extrinsic] evidence .... .); Davis v. Davis, 207 P. 1065, 1066-67 (Okla. 1922) (refusing to "express[] any opinion as to the admissibility of [extrinsic] evidence [regarding signatory intent]" but, notably, continued by broadly considering many factors to conclude that the proposed will lacked testamentary intent).

109. Cf. In re Estates of McLean, 231 P.3d 727, 732-33 (Okla. Civ. App. 2009) (Hanson, P.J., dissenting) (reiterating precedent that the law where a will is executed forms part of that will and challenging the majority's prohibition of extrinsic evidence to establish disinheriting intent given contrary rule in state of testator's domicile and will execution).

110. Foote v. Carter, 357 P.2d 1000, 1003 (Okla. 1960) (rejecting the employment of technical words as requisite to a valid holographic will).

111. In re Estate of Rigsby, 843 P.2d 856, 857 (Okla. Civ. App. 1992) (internal quotation marks omitted). 
have what I leave"; 112 "if I should die first I want you and your heirs to have what I have left"; 113 "[s]hould anything happen to me that I should be incapable of handling my business or in case of death the contents of this box are to be turned over to [the named parties]"; ${ }^{114}$ and "To Whom it may Concern" followed by statement of decedent's intent regarding the disposition of certain items and referring to a disposition to take effect after the maker's death. ${ }^{115}$ Professors McGovern and Kurtz state that "cases of holographs where testamentary intent is doubtful are probably rarer than those in which a testator's clear intent to devise property was frustrated because the jurisdiction did not recognize holographs." 116 The preceding samples reveal that similar problems can result even in a jurisdiction that does.

A circumvolutory example that effectuates probable testamentary intent but at the expense of tortured primary and secondary intent analysis lies in the peculiar case of Johnson v. Johnson. ${ }^{117}$ The decedent, a lawyer, prepared a one-page, typed document clearly reflecting testamentary intent-at least insofar as the nature of the document-but completely lacking witnesses. ${ }^{118}$ He then appended a handwritten, dated, and signed "codicil," which stated little more than that the will was complete. ${ }^{119}$ The court determined that although all writings appeared on the same page, the handwritten appendage constituted a distinctly valid holograph—a second will—-that republished the earlier typed and invalid one by codicil. ${ }^{120}$

112. Craig v. McVey, 195 P.2d 753, 754 (Okla. 1948) (internal quotation marks omitted). To be fair, in refusing to accord testamentary intent to that language, the Craig court noted that (1) the letter was one of many letters written to the same proponent; (2) the letter was "similar in tone" to those written to other persons; (3) the purported testamentary portion was but a small piece of a longer casual writing principally focused on unrelated issues; (4) the quoted language could as easily reflect the writer's present intent to effect a future will—non-testamentary intent-as her present intent to effect a present will — testamentary intent; (5) the decedent was familiar with testamentary terminology, having written an attested will some years before; and (6) in the eleven years between the letter's post and its writer's death, there was no evidence reflecting her belief that she had made a testamentary disposition thereby. Id. at 754-55.

113. In re Estate of Young, 219 P. 100, 100 (Okla. 1923) (internal quotation marks omitted).

114. Hooker v. Barton, 284 P.2d 708, 709, 710 (Okla. 1955) (internal quotation marks omitted).

115. In re Purcell's Estate, 176 P.2d 986, 986, 987 (Okla. 1947) (internal quotation marks omitted).

116. MCGOVERN \& KURTZ, supra note 7, § 4.4.

117. 279 P.2d 928 (Okla. 1954) (per curiam).

118. Id. at 929,930 .

119. Id. at 929 .

120. Id. at 932. Had the handwriting been viewed as an extension of the invalid typed document rather than a new and separate valid instrument republishing or incorporating the invalid typed document, the will should have failed under either holographic or attestation requirements, as it was 
A will that is invalid to begin with can never be republished; there can be no codicil without an original will. The Johnson Court maneuvered those realities with a definitional two-step: "a will may be so defective, as here, that it is not entitled to probate but if testamentary in character it is a will, nonetheless." ${ }^{21}$ Shocking as that statement may appear, it remains good law, and subsequent cases, some of which remain in force, continue to invoke the precedent. ${ }^{122}$

Thus, even where judicial pronouncement on the issue of testamentary intent and its proof superficially seems direct and expansive, the questions permit no easy answers given the tensions between what courts say, what courts mean, and what courts actually do.

\section{Arkansas: Definitional and Evidentiary Indecision}

The Arkansas experience aptly illustrates the discord inspired by the interplay between ambiguous definitions of a "will," the search for testamentary intent, and the admissibility of extrinsic evidence. In Edmundson v. Estate of Fountain, the decedent handwrote, signed, and dated an instrument titled "Last Will," which listed all of her children and inserted specific property items under each child's name. ${ }^{123}$ The document, fortuitously found in an upholstery roll a year after the decedent's death, left most of the estate to her youngest child who had lived next door and had provided assistance throughout the decedent's life. ${ }^{124}$ Along with arguably meeting jurisdictional requirements for a valid holograph, the instrument had been witnessed by two of the decedent's acquaintances. ${ }^{125}$ At trial on the admission of the putative will, both witnesses testified that they had signed the document after the decedent had asked them for a favor and then produced the subject instrument. ${ }^{126}$ Additionally, the decedent's sister testified that the decedent had told her that she had a will. ${ }^{127}$

neither "entirely in the handwriting of the decedent" nor properly witnessed. See id. at 935-36 (Halley, J., dissenting).

121. Id. at 930 (per curiam).

122. See, e.g., Pepper v. Peacher, 742 P.2d 21, 24 (Okla. 1987).

123. 189 S.W.3d 427, 428-29 (Ark. 2004).

124. Id. at 428.

125. Id. at $428-29$.

126. Id. at 429 .

127. Id. 
The trial court refused to admit the instrument to probate as the decedent's will on the grounds that there was " "no testamentary language whatsoever within the instrument.",128 On appeal, the reviewing court reversed course. ${ }^{129}$ After recognizing "long-standing” precedent finding testamentary intent crucial, the appellate court concluded that property-dispositive words "of a testamentary nature" were not required by applicable precedent and held that the decedent's testamentary intent was clear. ${ }^{130}$

The Supreme Court of Arkansas reinstated the trial court's order because it had not "clearly erred."131 The court concentrated on evidentiary matters. It reiterated its conviction that "[a] will is a disposition of property." 132 It affirmed that testamentary intent is "the intention to dispose of" property at death ${ }^{133}$ and must be unmistakably found by looking to and not beyond the document's face. ${ }^{134}$ Strikingly, the court acknowledged binding precedent that where the existence of testamentary intent was in doubt, "'inquiry may be made into all relevant circumstances.”,"135 The court equivocated, however, by explaining that the rule applied only where "some" testamentary intent "[could] be inferred from the four corners of the document itself."136 Apparently continuing with attempts to mask the tell in the precedent it had just cited, the court immediately followed with an internally inconsistent syllogism:

It is axiomatic that use of extrinsic evidence is appropriate only when the instrument contains some words expressing an intent to dispose of property; stated another way, it is inappropriate when the instrument expresses no such words of disposition. That is so because the existence of testamentary intent is not a matter of inference; rather, it must be expressed so that no mistake is made as to the existence of that intention. ${ }^{13}$

\footnotetext{
128. Id. (emphasis added).

129. Id.

130. Id.

131. Id. at 432.

132. Id. at 430 (citing Faith v. Singleton, 692 S.W.2d 239, 242 (Ark. 1985); Clark v. Rutherford, 298 S.W.2d 329, 330 (Ark. 1957)).

133. Id. (citing Smith v. Nelson, 299 S.W. 2d 645, 646-47 (Ark. 1957)).

134. Id. (citing McDonald v. Petty, 559 S.W.2d 1, 2 (Ark. 1997)).

135. Id. at 431 (quoting Chambers v. Younes, 399 S.W.2d 655, 657 (Ark. 1966)).

136. Id. (citing Faith, 692 S.W.2d at 242; McDonald, 559 S.W.2d at 2).

137. Id. (citations omitted) (citing David Terrell Faith Prophet Ministries v. Estate of Varnum, 681 S.W.2d 310, 312-13 (Ark. 1984); McDonald, 559 S.W.2d at 2).
} 
The court closed by quickly dispatching additional difficulties posed by an earlier opinion in which it stated that the document itself "along with all the attending circumstances" must overcome any extant doubts about testamentary intent: ${ }^{138}$

[That case] failed to mention ... that, when a document sets forth no words of a dispositive nature, it is defective on its face because it lacks the required intent to make a will, and extrinsic evidence is not admissible to prove the necessary intent. Thus, to the extent [it] conflicts with this ruling, it is hereby overruled."139

Only where a lower court can hold a document "utterly devoid" of the intent that the appellate court calls clear and where a supreme court can turn "permissible inferences" into a requirement for unmistakable facts, can a handwritten, signed, dated, and witnessed document captioned "Last Will" and tying specific pieces of property to specific persons fail to provide "some inference" of testamentary intent.

\section{Montana: Money, Power, and Evidentiary Litigation}

Contrast the preceding case, where testamentary intent seems facially clear on a witnessed document but succumbs to the court's refusal to admit extrinsic evidence, with the next, where testamentary intent seems facially absent under circumstances where its writer would know better, but is located after broad evidentiary mandates that seem to invert definitional ones.

Charles Kuralt was well-known for his CBS series On the Road. ${ }^{140}$ In 1968, he met Pat Shannon while on business; although he was then married, they began a close personal and financial relationship that lasted until his death some thirty years later. ${ }^{141}$ In the mid-1980s, Kuralt purchased adjacent parcels of property in Montana, the first covering

138. Id. at 432 (emphasis added) (citing In re Estate of O’Donnell, 803 S.W.2d 530 (Ark. 1991)).

139. Id. (citations omitted) (citing Dunn v. Means, 803 S.W.2d 542, 543 (Ark. 1991)). The dissent chided the majority and reminded that the power to overrule precedent should be used only where adherence to precedent would result in "great injury or injustice." Id. at 433 (Dickey, C.J., dissenting) (citing Union Pac. R.R. Co. v. Barber, 149 S.W.3d 325, 337 (Ark. 2004)). The internecine debate must have touched a nerve. The majority parried in part with an equally procedural thrust: after noting that the Restatement (Third) of Property permits extrinsic evidence to establish testamentary intent, the court stated that "the idea to apply or adopt the Restatement comes from the fertile minds of the dissenters, not the parties.” Id. at 432 n.3.

140. In re Estate of Kuralt (Kuralt I), 981 P.2d 771, 772 (Mont. 1999).

141. Id. The "second family" relationship included substantial monthly economic support and payment for Shannon's children's graduate school tuition. Id. at 773. 
twenty acres and the second two parcels comprising ninety additional acres near the original acquisition. ${ }^{142}$ Kuralt and Shannon intended the property for eventual retirement use. ${ }^{143}$

In May of 1989, Kuralt executed a valid holographic will stating, "In the event of my death, I bequeath to Patricia Elizabeth Shannon all my interest in land, buildings, furnishings and personal belongings [in the Montana property]." 144 Five years later, however, he executed a formal will in favor of his spouse, Petie. ${ }^{145}$ It contained a standard revocation clause, devised all residential or vacation real property to his spouse, left the residue to his spouse and their children, and failed to name Shannon as a beneficiary. ${ }^{146}$ Petie was unaware of Kuralt's relationship with Shannon until after he died, ${ }^{147}$ and Shannon was similarly unaware of Kuralt's attested will. ${ }^{148}$

In the spring of 1997, Kuralt deeded the original twenty-acre Montana parcel to Shannon, which, while structured as an arms' length purchase and sale, was actually consummated through funds Kuralt had previously provided Shannon to accomplish that very end. ${ }^{149}$ Although Kuralt and Shannon were to meet the following fall to complete similar sham transactions over the remaining acreage, Kuralt fell ill in the interim. ${ }^{150}$ Writing from a New York hospital to which he had been admitted that very day, Kuralt handwrote, signed, and dated a short letter to Shannon expressing grave concern over his health and stating, "I'll have the lawyer visit the hospital to be sure you inherit the rest of the place in MT. [I]f it comes to that." "151 Kuralt sent the letter to Shannon, enclosing checks totaling $\$ 17,000 .{ }^{152}$ He died shortly thereafter without executing any subsequent will or codicil formalizing his intent. ${ }^{153}$

Petie filed in New York to probate Kuralt's Montana property; within the month, Shannon sought ancillary probate by alleging that Kuralt's letter met formal requirements for a valid holographic will and

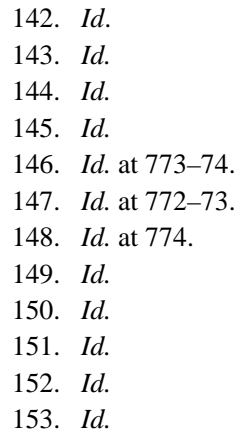


claiming entitlement to the remaining acreage of the subject Montana land. ${ }^{154}$ Kuralt's estate sought summary judgment on grounds that the letter lacked testamentary intent by expressing, at most, a future intent to make a will. ${ }^{155}$ After hearing extrinsic evidence allegedly bearing on testamentary intent, the district court partially granted the estate's motion. ${ }^{156}$ It held that the letter "clearly contemplates a separate testamentary instrument not yet in existence to accomplish the transfer of the Montana property."157 In Kuralt I, the Montana Supreme Court reversed and remanded. ${ }^{158}$ Over a strong dissent filed by the Chief Justice, ${ }^{159}$ the court marshaled standard summary judgment principles to conclude that extrinsic evidence raised a genuine issue of material fact over testamentary intent. ${ }^{160}$ Interestingly, however, the court cast that question as whether Kuralt intended to give rather than sell the property to Shannon, rendering it but a short step to note that the gift's timing could have been contemplated as to occur at death and thus reflect testamentary intent. ${ }^{161}$

To the court, its holding avoided the need to reach the second issue framed on appeal: whether ambiguity as to a document's intent was a prerequisite to the admission of extrinsic evidence to prove it. ${ }^{162}$ Nevertheless, the court spent a good deal of energy on dicta so as to guide the proceedings on remand given that the parties had spent significant energy contesting the issue. ${ }^{163}$ Citing statute, the court noted that the legislature had not expressly deemed ambiguity as necessary for —or in qualification of a court's discretion regarding — the admission

\footnotetext{
154. Id. at 771-72.

155. Id. at 772 .

156. Id.

157. Id.

158. Id. at 778 .

159. The dissent objected on grounds that the letter "“clearly contemplate[d] a separate testamentary instrument not yet in existence to accomplish the transfer of the Montana property.'” Id. at 778 (Turnage, C.J., dissenting). This fell short of the statutory requirement that a document can only constitute the decedent's will upon "clear and convincing evidence" that the decedent so intended. Id. (citing MONT. CODE ANN. § 72-2-523 (2011)). To the dissent, neither the record nor the letter met that standard. Id. According to the dissent, the letter merely reflected with precatory, non-imperative, and indirect language Kuralt's intent to accomplish a will in the future rather than intend it, itself, to so serve. Id.
}

160. Id. at 778 .

161. Id. at 776 (majority opinion).

162. Id. at 776-77.

163. Id. 
of extrinsic evidence. ${ }^{164}$ The court continued by invoking what it characterized as a longstanding rule:

All that is necessary to make an instrument testamentary is that it should show, when read in connection with surrounding facts and circumstances, a testamentary intention.... [I]f the intention of the testator is left in doubt by the form of expression used, then the intention must be arrived at by considering it in the light of the surrounding circumstances, and the intention must clearly appear. ${ }^{165}$

Although the court remonstrated that extrinsic evidence could never "manufacture testamentary intent" where such intent is "clearly absent" on the writing's face, the court nevertheless excluded Kuralt's letter from this narrow category given his history-gift-giving and otherwise-with Shannon, the exigency of the letter's writing, and its use of the word "inherit" as attached to the Montana property. ${ }^{166}$ The court so found notwithstanding its nod to the necessity of present testamentary intent defined as "intent that the very letter constitute a valid holographic codicil to his Last Will.”167

Although its preceding analysis intimated that (1) ambiguity was not necessary to the admission of extrinsic evidence, ${ }^{168}$ and (2) it did not see fit to rule on the issue in any event, ${ }^{169}$ the court closed with confusion: "Because Mr. Kuralt's letter is unclear as to testamentary intent, the District Court properly admitted extrinsic evidence bearing upon Mr. Kuralt's intent in the summary judgment proceeding. The court should,

164. Id. at 777; accord MONT. CODE ANN. § 72-2-522(3) (2011) ("Intent that the document constitute the testator's will may be established by extrinsic evidence, including, for holographic wills, portions of the document that are not in the testator's handwriting.”); MONT. CODE ANN. § 282-905(2), (3) (2011) ("This section does not exclude other evidence of the circumstances under which [an agreement, including a will,] was made or to which it relates, as described in 1-4102 ....”); MONT. CODE ANN. § 1-4-102 (2011) (permitting the circumstances under which an instrument was made, including its situation and its affected parties, to be shown "so that the judge be placed in the position of those whose language he [or she] is to interpret”).

165. Kuralt I, 981 P.2d at 777 (majority opinion) (quoting In re Noyes’ Estate, 106 P. 355, 358 (Mont. 1909)) (internal quotation marks omitted); cf. In re Estate of Ramirez, 869 P.2d 263, 265 (Mont. 1994) ("Whether sufficient testamentary intent is present in an alleged will should be determined by first looking to the writing itself. However, if the intent is not clear from the writing, then the surrounding circumstances may be considered." (citations omitted)). Note that Ramirez appears to import an ambiguity prerequisite to the admission of the extrinsic evidence.

166. Kuralt I, 981 P.2d at 777-78.

167. Id. at 778 (emphasis added).

168. Id. at 777 .

169. Id. at $776-77$. 
therefore, also admit all [germane] extrinsic evidence ... when the issue goes to trial." 170

After remand, the trial court again reviewed Kuralt's letter and found, after an abbreviated evidentiary hearing, that testamentary intent did exist. ${ }^{171}$ Appeal was distilled to whether the trial court erred in finding present testamentary intent and in refusing the parties an opportunity to be heard on the codicil status of the 1997 letter. ${ }^{172}$ With little discussion and no dissent, the court answered both questions in the negative and affirmed the lower court's order and judgment. ${ }^{173}$

The Estate of Charles Kuralt reached the Montana Supreme Court twice more: first on litigation over who held priority to serve as personal representative for the estate ${ }^{174}$ and next on litigation over whether the residuary estate left to Kuralt's wife and daughters held the estate tax burden on the transfer of the Montana property. ${ }^{175}$ One wonders whether the disposition of Kuralt's testamentary intent at trial could have avoided such serial litigation.

These brief examples reveal the tautologies involved. A jurisdiction's definition of testamentary intent can affect the perceived clarity with which it is expressed and, in turn, the document's ambiguous-unambiguous categorization for purposes of accessing extrinsic evidence. Likewise, a jurisdiction's answers to the evidentiarysource question can affect the likelihood of a document's proponent proving testamentary intent to begin with. That both issues independently confront confusing, if not competing, inter- and intrajurisdictional treatment makes them even more difficult when joined. And these observations do not even begin to address some deeper structural difficulties that testamentary intent has raised.

\footnotetext{
170. Id. at 778 (emphasis added).

171. In re Estate of Kuralt, 15 P.3d 931, 933 (Mont. 2000).

172. Id. at 932.

173. Id. at 934. First, the court rejected the estate's contention that the trial court had erroneously supposed an "uninterrupted intent to transfer" the subject property, between Kuralt's 1989 and 1997 holographs, notwithstanding the intervening 1994 attested will. Id. at 933-34. Reiterating the procedural posture of the case in which factual findings would not be disturbed unless clearly erroneous, the court characterized the Estate's argument as one of fact and determined that the record disclosed sufficient evidence of Kuralt's donative intent, impending death, and desire to conceal his relationship with Shannon to support the trial court's holding. Id. at 934 .

Second, the court rejected the Estate's claim of trial court error in finding the 1997 letter to be a valid codicil to the attested will without offering the parties an opportunity to be heard. Id. To the court, the letter was a codicil as a matter of law. Id.

174. In re Estate of Kuralt, 30 P.3d 345, 348-49 (Mont. 2001).

175. In re Estate of Kuralt, 68 P.3d 662, 663 (Mont. 2003).
} 


\section{ELUSIVENESS EXPLAINED}

That which is common to both law and most psychologies includes various "inner states" such as thinking, feeling, wishing, deciding, and the like - and they are not easily explored.... In most psychologies such internal states comprise highly important data; in psychiatry they concern the central problems .... These data are relatively uncertain; they are discoverable only by indirection, and some of them, e.g., "the unconscious," require very elaborate techniques to become known. ${ }^{176}$

Intent is adjunct to action throughout law and turns accident into assault, manslaughter into murder, and, occasionally, casual instruments into a Last Will and Testament. Acts are settled and past; they are capable of factual proof positive in a way that pure intent-like opinion-can rarely be. Although less diffuse than free-floating thought, intent remains subjective and connotes that something will occur in the future. It is a precursor to-rather than post hoc justification forconduct and resultant perceived and felt effect, whether relatively simultaneous or attenuated in time. If intent itself is subjective, so too will be much of the evidence of its existence.

The legal contours of intent thus can confound no matter the field"rather obscure" within criminal law, ${ }^{177}$ "not sufficiently nuanced" for torts. $^{178}$ That said, what is it about intent that seems to heighten its difficulty when encountered in testamentary form? A facile response would simply reiterate what Part III already addressed - the definition of the term, the divergence of approach over its proof, and the interconnection between the two. Yet there is more beneath that surface. Testamentary intent is elusive because irrespective of its definition, it can be difficult for an individual even to form. Relatedly, irrespective of the manner of its proof, it can be difficult for a court to identify that it was, in fact, formed. The unique forward- and backward-looking context of a

176. Jerome Hall, GeNeral Principles of CRiminal LAW 486 (1947).

177. Wayne R. LaFave, Criminal LaW $\S 5.2$ (4th ed. 2003). Professor LaFave's treatise reflects the jurisprudential difficulty through its attempt to articulate and sort the mental states of criminal intent, "state of mind," scienter, or “mens rea." See generally id. §§ 5.1-.6 (reflecting the ambiguity in defining mental states).

178. Kenneth W. Simons, A Restatement (Third) of Intentional Torts?, 48 ARIZ. L. REV. 1061, 1093 (2006) (“[Legal reform should] specify whether intention means purpose, knowledge, or both. Indeed, even the distinction between purpose and knowledge is not sufficiently nuanced. There are more than two categories of legal 'intention.' Tort doctrine actually employs at least four categories and some subcategories ....”.). 
will's execution and interpretation, respectively, exacerbate these difficulties.

\section{A. Individual Formation of Testamentary Intent}

Perhaps the inter vivos gift—which essentially requires donative intent, delivery, and acceptance ${ }^{179}$ — provides the most appropriate analog for exploring the interplay between testamentary intent and testamentary act. With gifts, law ratchets up intent by requiring present donative intent to effect a present transfer; ${ }^{180}$ intent formed today is insufficient if I plan to act on it tomorrow. Physical delivery, which relinquishes dominion and control of the subject property, most clearly manifests this intent. ${ }^{181}$ As such, delivery both fulfills the second gift requirement and proves up the first. Law closes the gift upon a donee's acceptance. ${ }^{182}$

Pure gifts are traditionally a zero-sum game. Given the convention of possession as nine-tenths of the law, requiring intent plus delivery and acceptance ensures that all parties immediately appreciate at legal and practical levels exactly what has taken place. ${ }^{183}$ Donors who part with their property realize that they may no longer use, possess, control, transfer, enjoy, consume, destroy, or exclude others from it, and donees who accept delivery know that they will ordinarily gain that full measure of ownership with all of the rights and responsibilities thereby entailed. A donor may not revoke a completed gift. ${ }^{184}$ The erstwhile owner may regain title only through a subsequent reconveyance from the donee.

Contrast the will. Notwithstanding the casual view that it is simply a subset of a donative transfer that triggers at death rather than during life, the inter vivos construct does not so neatly square. First, although pure testamentary and donative intent are both consideration-free, testamentary intent uniquely conditions itself upon some future, although unavoidable, event-death. Therefore, one may always amend or revoke the intent whether already "acted upon" through a validly executed will or not. Second, the act of executing the will supplants the delivery

179. See, e.g., Gruen v. Gruen, 496 N.E.2d 869, 872 (N.Y. 1986); RAY ANDREWs Brown, THE LAW OF PERSONAL PROPERTY § 37 (2d ed. 1955).

180. Gruen, 496 N.E.2d at 872.

181. See id. at 874 .

182. See id. at $874-75$.

183. Id. at 874 (noting that the purpose of delivery is "to avoid mistakes by donors and fraudulent claims by donees").

184. See id. at 872 . 
demanded for an inter vivos gift. Like delivery, execution-particularly when highly ritualized-provides proof of intent. ${ }^{185}$ Unlike delivery, however, executing a will-a revocable document legally silent until death $^{186}$-holds no immediate and final consequence for either the donor or the donee. Obviously, no possession of the designated property shifts. Its owner continues with all ownership rights-including total consumption-until death.

Thus, testators perceive and actually suffer zero diminution in property rights, and the difficulty with which most apprehend the loss of their property or their lives heightens a justifiable blitheness. ${ }^{187}$ Reciprocally, beneficiaries neither perceive nor actually enjoy an iota of legal gain under an executed-but-not-yet-effective will, even in the unlikely event that they are aware of the precise person-to-property matches it holds. ${ }^{188}$ In sum, traditional sources will instruct that a putative beneficiary holds only the "expectancy," which no matter how ill-defined, is currently no property interest at all. ${ }^{189}$ Assuming that they even arise, the convergent realizations that holding testamentary intent and acting upon it work no change to either the legal relationship of the parties or their practical or possessory relationship to the property preserves the mystery of the will. If, in turn, individual and judicial understanding of the will remains obscure, testamentary intent is susceptible to being more indefinitely and ambiguously formed and expressed by expectant testators, ignored by expectant takers, and disregarded by courts.

\section{B. Judicial Identification of Individually Formed Testamentary Intent}

Although intent is elusive no matter the field, it is often more clearly formed or found outside of the testamentary context—or perhaps because

185. Langbein, Substantial Compliance, supra note 34, at 492-93.

186. The one arena in which a will might have effect immediately upon execution is to revoke a prior document, especially where revival of prior wills is either not permitted or is contingent on clear proof of intent. RESTATEMENT (THIRD) OF PROPERTY: Wills \& OTHER DonAtive TRANSFERS § $3.1 \mathrm{cmt}$. a (1999).

187. McBride v. McBride, 67 Va. (26 Gratt.) 476, 484-85 (1875) ("[The] spirit of procrastination and delay in regard to the execution of last wills and testaments . . . so often springs from youth and health and the confidence in a long life.”).

188. In that title will not transfer-if ever-until death, beneficiaries need not accept upon execution. Although presumed, acceptance is deferred until probate as mediated through assignment, release, or renunciation - the deathtime equivalents of refusing to accept a gift.

189. Katheleen R. Guzman, Releasing the Expectancy, 34 ARIZ. ST. L.J. 775, 786 (2002). 
its identification drives the assignment of civil or criminal liability with attendant shifts in the evidentiary burden, it is at least more amenable to identification and (dis)proof.

\section{Intent and Conduct Coincidence}

The cleanest perspective from which to assess the existence of intent occurs when it coincides with action, permitting observers to intuit confidently that the desire precipitated the conduct, which itself would not have occurred but for that desire. ${ }^{190}$ If so, intent is best formed, refined, and established through neither thoughts nor words, but deeds. As earlier discussed, gift law so instructs by requiring donors to feel the "wrench of delivery," 191 with donative intent unenforceable until the donor actually makes the play. Moreover, such confluence of intent and conduct is even more clear in legal contexts where the intent-holder both appreciates and must at least partially internalize the effects of acting upon it, and must already have done so for the subject litigation to have been brought.

Crimes and torts provide ready examples. "Bad thoughts alone cannot constitute a crime"; ${ }^{192}$ there must be correlative criminal conduct linking actus reus with mens rea. ${ }^{193}$ Similarly, although irrelevant to negligence or strict liability, "intent by itself is never a tort."194 Intentional torts require some actionable conduct serious enough to

190. A common maxim states that one is presumed to intend the natural and probable, or ordinary, consequences of his acts. See, e.g., Jeremiah Smith, Surviving Fictions, 27 Y ALE L.J. 147, 157 (1917).

191. Langbein, Substantial Compliance, supra note 34, at 504 (noting that the process of conveyance achieves the "wrench of delivery").

192. LAFAVE, supra note $177, \S 6.1$. The rule remains notwithstanding the medieval doctrine that voluntas repubtabitur pro facto, or the intention is to be taken for the deed. Id. $\S 11.2$ (discussing the crime of attempt).

193. See George P. Fletcher, Manifest Criminality, Criminal Intent, and the Metamorphosis of Lloyd Weinreb, 90 YALE L.J. 319, 337 (1980) (referencing "the venerable maxim that a crime requires (1) an act, (2) an intent, and (3) the coincidence of the act and the intent at some moment in time”); cf. Marcel Frym, The Criminal Intent, 31 TEX. L. REV. 260, 261 (1953) (challenging the construct of criminal law, which is premised on "the time-honored assumptions that human actions presuppose formation of a conscious intent and that forming intent is exclusively a function of the human mind as a free agent”). Professor Fletcher notes Sir Edward Coke’s observation: “'Actus non facit reum, nisi mens sit rea [no act is criminal unless accompanied by a criminal intent].”' Fletcher, supra, at 321 (quoting EDWARD COKE, THE THIRD PART OF THE INSTITUTES OF THE LAWS OF ENGLAND 107 (1669)).

194. DAN B. DOBBS, THE LAW OF TORTS $\S 24$ (2000). Tortious intent exists when an actor “(1) has a purpose to accomplish [a] result or (2) lacks [the] purpose but knows to a substantial certainty that the ... action will bring [it] about." Id. 
support the claim. Without conduct, intentional-tort liability or criminal prosecution would be a nonutilitarian nightmare, unfair to enforce, impossible to police, and lacking any deterrent benefit to offset the costs. Without intent, punishment could be futile, immoral, or worse. The same cannot be said of the will. That the law has already divorced intent from conduct for purposes of the will in all but the most rigidly strict of jurisdictions reveals that, unlike torts and crimes, their coupling is no longer viewed as indispensable to the enforceability of either.

Intent and conduct can be mutually reinforcing. With torts and crimes, the nature of the conduct and the harmful results it occasions often make the legal assignment of intent so clear-or at least transferrable from one intended result to another-that no room exists for rational doubt over its presence. ${ }^{195}$ To use a simplistic example, most people most of the time would presumably feel comfortable assuming that $A$ would neither raise toward nor let fall a claw-backed hammer upon B's head without intending, or at least being recklessly indifferent to, a specific, serious result. Most courts would be similarly confident in the rectitude of ensuing criminal conviction or civil liability, or at least safe in knowing that heightened proof burdens will cover the instances where intent is questionable. Criminal and tortious conduct are things that the average person can generally see and recognize for what they are and the intent they may reflect. A potential actor probably appreciates the sorts of acts that constitute crimes or intentional torts. So he either does not intend them and thus does not so act, or he does intend them and thus acts-but hopes not to be caught. The same cannot be said within wills law, where intent and statutorily compliant conduct are more fluid and less intuitive. Moreover, the conduct from which intent could be extrapolated might be much more commonplace outside of the legal realm than a hammer attack on a third party: like a letter written to a relative, a day's entry into a diary, or a note to an attorney.

The lessened difficulty that intent poses to contract formation and breach supports similar analysis, not because assumptions and outcomes

195. The theoretical underpinnings for res ipsa loquitur-the thing speaks for itself-although traditionally limited to negligence, are analogous. See RESTATEMENT (SECOND) OF TORTS $\S 328 \mathrm{D}$ \& cmt. j (1965).

The doctrine does find some application within criminal law, under which an act constitutes the crime of attempt when it can have no other reasonable purpose than the commission of the intended crime. LAFAVE, supra note 177, § 11.4(d). Although accepted by some courts and legislatures, this so-called "equivocality approach" has not found much favor with scholars. Omri Ben-Shahar \& Alon Harel, The Economics of the Law of Criminal Attempts: A Victim-Centered Perspective, $145 \mathrm{U}$. PA. L. REV. 299, 325 (1996). 
render intent easy to locate, but rather because it is no longer needed at all. Modern contract theory sidesteps many intent-associated difficulties by replacing the older subjective, individual intent-based approach ${ }^{196}$ with the "objective theory" of assent whereby conduct controls. Judge Learned Hand insisted:

A contract has, strictly speaking, nothing to do with the personal, or individual, intent of the parties. A contract is an obligation attached by the mere force of law to certain acts of the parties, usually words, which ordinarily accompany and represent a known intent. If, however, it were proved by twenty bishops that either party, when he used the words, intended something else than the usual meaning [that] the law imposes upon them, he would still be held, unless there were mutual mistake, or something else of the sort. ${ }^{197}$

As such, a party's intent to be contractually bound is largely irrelevant; it is the act and what it objectively, reasonably manifests that supplies the legal result, rather than an intent as furthered, established, or proved by that act. ${ }^{198}$ The sham-will cases illustrate that similar act-intent decoupling has not occurred within the testamentary realm. ${ }^{199}$

Even absent incontestable evidence of contract law's traditional offer, acceptance, and consideration trio ${ }^{200}$ through expressly manifested intent, reasonable reliance (itself a close variant of both conduct and intent) can either form the consideration necessary for a putative contract or sustain an independent theory of recovery. ${ }^{201}$ Moreover, courses of dealing and performance provide evidence through conduct and can

196. See 1 E. Allan Farnsworth, Farnsworth ON CONTRACTS §3.6 (3d ed. 2004) (comparing subjective and objective theories and noting the universal acceptance of the objective theory today).

197. Hotchkiss v. Nat'l City Bank of N.Y., 200 F. 287, 293 (S.D.N.Y. 1911), aff'd sub nom. Ernst v. Mechs. \& Metals Nat'l Bank of N.Y.C., 201 F. 664 (2d Cir. 1912), aff'd sub nom. Nat'l City Bank of N.Y. v. Hotchkiss, 231 U.S. 50 (1913), quoted in 1 FARNSWORTH, supra note 196, § 3.6.

198. Id.

199. See supra Part III.C.

200. See, e.g., Robert CoOter \& Thomas Ulen, LAW \& Economics 190 (4th ed. 2004) (describing offer, acceptance, and consideration requirements). While the Statute of Frauds promotes a particular sort of conduct when demanding that certain contracts be written, massive exceptions exist through part performance and equitable estoppel. See generally 2 FARNSWORTH, supra note 196, $\S \S 6.9,6.12$ (discussing part performance and reliance with respect to the Statute of Frauds). Both theories recognize that at least some conduct-through performance or reliancesupporting at least some demonstrable intent or evidencing the underlying agreement, will have occurred. See id.

201. See 1 FARNSWORTH, supra note 196, § 2.19 (describing reliance as an independent grounds for recovery). 
reliably demonstrate the existence and boundaries of parties' intent to be bound.

Although interpretive difficulty over intent generally eases when it coincides with conduct and performance with presumably immediate consequences for the actor and other implicated parties, such easing might infrequently occur within the category of testamentary intent given its appreciably intrinsic attenuation of intent, conduct, and outcome. This analysis-act and effect instigating or proving intent and vice versa-begs a related question: assuming a would-be testator's clear understanding of testamentary intent, what correlative action completes it? Execution of the will itself? The later death of its testator with that will intact? Neither answer is trouble-free when seeking reliable indicators of intent.

An initial question exists regarding the definition and timing of the intent and the conduct. As legally marked, testamentary intent occurs at execution with the commensurate and simultaneous conduct combining to create an acceptable document. ${ }^{202}$ More abstractly, however, as the will speaks only at death and not before, the actual fulfillment or performance of either the intent or act component could shift to the point at which the decedent dies leaving a previously executed will intact. Additionally, wills have no shelf life. Significant time can elapse between formation of testamentary intent and execution, execution and death, or formation of testamentary intent and death. While a will executed a day before death more convincingly secures the recency and primacy of the testator's stated desires matched to extant circumstances, it is no more valid than one executed decades before. A longer gap between the expression of arguable testamentary intent and death-when testamentary intent becomes relevant-increases the possibility that memories will fade, witnesses will die, and already-fragile evidence will weaken in turn.

Contrast, for example, a typical sale of goods, where intent is formed and performance, through payment, transfer, and acceptance, occurs in close temporal proximity. Although contracts are bilateral, wills are not.

202. Testamentary intent must exist at a will's execution. See, e.g., Fleming v. Morrison, 72 N.E. 499, 500 (Mass. 1904) (noting that the "animus testandi" must exist when the will is signed or acknowledged). Note the slight difference in the following formulations: (1) present intent to transfer either a present or future interest can support a gift, and (2) present intent to transfer a present or future interest in the future is a will. The two can be hard to distinguish, particularly where the donor retains a life estate in the subject property or conditions its transfer upon death. See, e.g., Gruen v. Gruen, 496 N.E.2d 869 (N.Y. 1986). 
As there is no such thing as the legal "performance" of a will, time deadlines are nonexistent, much less "of the essence." Even from the abstract perspective of performance as equaling "death without revocation," it would still be impossible to discern when that "performance" will occur. ${ }^{203}$

\section{Intent, Conduct, and Relevant Actors}

The remaining evidentiary difficulties in establishing testamentary intent are already well-known. Dead men tell no tales, but living ones do; for crimes and torts, confessions or admissions might be the norm. Even when an alleged criminal refuses to testify or a tortfeasor withholds direct contemporaneous or subsequent evidence of culpable intent, she may be available for direct or cross-examination and attendant credibility assessment through observable conduct, facts, and the inferences or presumptions they yield. ${ }^{204}$ Again, contracts are analogous. As enforceable ones require both offer and acceptance, as well as consideration on both sides, ${ }^{205}$ there will always be at least two parties bearing a relevant intent with which to color the analysis or inform the result. Moreover, as contracts are formed between the living, there is no contextual determinant that one party must die by the time that litigation will arise.

A testator could die a day or a decade after executing a will. Irrespective of the temporal brevity between testamentary intent, will execution, and testator death, the very question over whether testamentary intent exists does not surface until probate, after the death of the sole party to have known with conviction whether it had been formed. $^{206}$ The inability to question a decedent over intent makes its

203. A will written in anticipation of suicide would be the only plausible scenario.

204. Moreover, while there are dead convicted criminals, there are no dead criminal defendants. Consider Enron founder Kenneth Lay's death: post-conviction, pre-appeal on conspiracy and fraud charges for "vaporiz[ing] more than 4,000 jobs and billions of dollars in stockholders' investments." Thomas S. Mulligan \& Miguel Bustillo, Death Puts Lay Conviction in Doubt, L.A. TIMES, July 6, 2006, at A1. The rule of abatement generally instructs that a criminal case is dismissed or vacated if the defendant dies without exhausting appeals. Durham v. United States, 401 U.S. 481, 482-83 (1971) (per curiam), overruled on other grounds by Dove v. United States, 423 U.S. 325 (1976) (per curiam); 13C Charles Alan Wright, ARThUR R. Miller \& EdWARD H. CoOper, Federal PRACTICE AND PROCEDURE $§ 3533.4$ (3d ed. 2008).

205. See COOTER \& Ulen, supra note 200, at 190.

206. Ante-mortem probate, where a testator can testify to her own intent, is a rare exception. See ARK. Code AnN. § 28-40-202 (West 2004 \& Supp. 2011); N.D. CENT. CodE ANN. § 30.1-08.1-01 (West 2008); OHIO REV. CODE ANN. § 2107.081 (West 2005). 
certainty tricky, invites interested parties to misremember or manufacture self-serving evidence, and removes impediments to factfinder bias in interposing their own intents or preferred modes of its expression.

\section{Elusiveness Re-Compounded}

If acts can instigate the formation of intent or clarify its subsequent proof and vice-versa, then the reliability of both is inversely proportionate to their temporal and effective separation from the severity of their consequences. Actors divorced from the immediate legal or felt effects of their action are less likely to internalize costs or minimize ambiguity. Neither putative, living testators nor actual, deceased ones personally suffer the effects of their own action, improvident or otherwise. Unlike the typical criminal, tortfeasor, contracting party, or even inter vivos donor, who, in living with the outcome of her choices, will presumably consider and act on intent in more deliberate ways, the pre-death conduct of testators regarding both their promises and their property most always externalizes its human or economic costs on heirs or beneficiaries, neither of whom are likely to hold much justifiable reliance on a particular outcome of that decedent's estate. For example, consider Charles Kuralt, who might have done things differently had he been there to witness five years of litigation between his wife and daughters and his mistress. ${ }^{207}$

As with Part III's discussion of the basics of testamentary intent doctrine itself, understanding exactly why it is elusive is equally frustrating. That circles seem to close in on themselves could leave courts or commentators more confounded than before. If so, indistinct rules and outcomes will remain, with doctrinal reformation viewed as a game not worth the candle.

\section{REFORMING TESTAMENTARY INTENT: WHY AND HOW}

\section{A. Why Reforming Testamentary Intent Matters}

Overlooking legal convolution can generate aberrational outcomes; ignoring it once discerned fares little better no matter the trials or tribulation that a closer look prompts. When a court imposes unconsidered doctrine on easy cases where the end result would not have

207. See supra Part III.C.3. 
differed anyway, one may easily ignore, or correct on appeal, design and application flaws. But when imposed on - or made for-harder cases, it may well inflict downstream costs on the parties, future litigants, the judicial system, and the societal values that system preserves and promotes. Most poignantly, it may adversely affect the realization of a particular decedent's last wishes and the testamentary freedom animated thereby.

The need for attention to testamentary intent has become even more acute over the past two decades, given the increasing recognition of its role in overcoming execution defects. ${ }^{208}$ As "formalism falls, intent rises"; as intent rises, heightened care must be afforded to its contours. ${ }^{209}$ Nowhere is this need more vivid than in jurisdictions adopting or influenced by the Restatement (Third) of Property and the Uniform Probate Code, which come closest to raising intent to a documentdeterminative position. ${ }^{210}$ But intent's intense pressure will continueand from expanded quarters-given trend lines in liberalized rulestandard interplay and the inexorable march of technological advance. ${ }^{211}$

\section{Costs and Inefficiencies}

Imprecision works its demerits at every participation level within the legal system, and the indistinct and unsound rules governing testamentary intent are no exception. First, these rules increase transactional burdens on the hopeful testator, who must take greater care to ensure that the subject document comports and reflects intent readily and clearly. From a least-cost-avoider perspective, this might seem optimal. That is, any marginal increase in the cost of expressive obligation-handily discharged through such words as "I intend this document to be my will"-is easily outweighed by the benefits in securing intent and avoiding the negative consequences of its

\footnotetext{
208. See Unif. Probate CodE art. II prefatory note (amended 2008), 8 U.L.A. 75 (1998).

209. See supra Part II; see also Lindgren, Formalism, supra note 9, at 1010, 1017-20 (discussing assorted components of testamentary intent).

210. See supra Part II.A.3.

211. Who knows how far and fast such things as videowills, videoconferencing, flash drives, email, disks, electronic signatures, and Skype will go in entering discussion over documents, signatures, presence, and testamentary intent. The questions are not new, but in a way, are just beginning. See generally Ronald K.L. Collins \& David M. Skover, Paratexts, 44 STAN. L. REV. 509 (1992) (discussing the role of new technologies in the legal system); Grant, supra note 12 (advocating acceptance of electronic technology in the law of wills).
} 
imprecision. $^{212}$ But notably, nebulous intent more likely affects the holographic will and, thus, testators who are less educated, with less testamentary acumen, less wealth, and less inclination or ability to visit lawyers. The effects of unclear, or clear but strict, intent rules on such a vulnerable population with less access to estate planning increases their unfairness. Moreover, that fewer dollars are actually at stake minimizes the downsides of broadening testamentary effect to cover more casual documents drafted by such parties.

Second, the current rules adversely affect particular would-be beneficiaries or heirs by forcing initial or appellate litigation over questions of intent, particularly in that highly probabilistic determination is low, given the parties' incomplete information over clear legal rules or litigation outcomes. $^{213}$ For documents accepted into probate, heirs or prior beneficiaries may challenge close questions of testamentary intent; ${ }^{214}$ current beneficiaries may respond in kind. Although both players would presumably handicap the reward discounted by time, cost, and risk, litigation - especially involving subjective, fact-intensive issues coupled with imprecise rules-is not cheap, particularly for the riskaverse. ${ }^{215}$ Windfall is possible for both.

Litigation depletes the resources of winners, losers, and the contested estate. $^{216}$ Even a successful malpractice suit would effectively increase

212. Thus, an ounce of $T$ 's prevention would be worth the pound of $B$ 's cure. Moreover, to the extent that a testator intentionally generates ambiguity, a possibility suggested by the sham-will cases, the costs imposed on $T$ would be particularly deserved.

213. For straightforward discussion of decision analysis accessible even to the uninitiated, see Howell E. JACKSON ET AL., ANALYTICAL MethodS FOR LAWYERS 1-33 (2003).

214. Less benign motivators exist. See Ted Sichelman, Why Barring Settlement Bars Legitimate Suits: A Reply to Rosenberg and Shavell, 18 CORnELl J.L. \& PUB. POL’y 57, 58 \& n.1 (2008) (identifying motivators such as extraction of "nuisance-value settlements," expectation of judicial error, possible spoliation of evidence or perjury, error in counter-party’s estimation of success).

215. Aside from a basic comparison of projected payoff to costs of reaching it, also relevant may be the worth of that payoff over the total estate. The higher both the projection and the ratio, the more likely the litigation. For example, compare a putative holograph simply bequeathing "the Klimt painting” with one transferring the entire estate.

216. Barring a fee-shifting statute, litigants generally bear their own costs rather than losers paying all. See, e.g., Sichelman, supra note 214, at 58-59 \& n.4 (discussing fee-shifting as an effort to combat frivolous litigation); see also John H. Langbein, Will Contests, 103 YALE L.J. 2039, 204344 (1994) [hereinafter Langbein, Will Contests] (reviewing DAVID MARGOLICK, UNDUE INFLUENCED: THE EPIC BATTLE FOR THE JOHNSON \& JOHNSON FORTUNE (1993)) (positing that this feature along with jury trial, unavailability of ante-mortem probate or anticipatory relief, and probate staffing, contributes to the higher incidence of will contests in the United States relative to other jurisdictions).

The estate typically subsidizes costs of the will defense and possibly also the costs of goodfaith claims, proponents of wills, putative will beneficiaries, prevailing contestants, and contest attorneys. 80 AM. JUR. 2D Wills § 959 (2002). Of course, actual takers actually bear these costs. 
the price of competent estate planning for a choir in no need of a sermon. $^{217}$

Economics and efficiency, however, are not the sole litigation determinants. Although net benefits may predominate in a true commercial setting between arms-length transactors, the probate context reflects and begets powerful emotions that can override economically rational decision-making. Sometimes a proponent consciously supports a will to uphold the perceived last wishes of a loved one, and sometimes, a challenger subconsciously resists a will to convince herself that she was truly loved. ${ }^{218}$ " "When I bring up the issue of inheritance with my mother, then, I am asking her not to abandon me to wanton circumstance, to mother me from the grave. It is a fantasy of absolute safekeeping I am requesting, one that will cradle me from life's indignities.",219

Third, whether eventually settled or not, indeterminate outcomes extract concomitant burdens on judicial economy. Consider the number of cases involving testamentary intent filed over the last two decades alone. ${ }^{220}$ More coherent doctrine would provide more sophisticated costbenefit information to the parties and decreased litigation overall, and increase the likelihood that the remaining cases warrant judicial involvement. If the current legal structure of testamentary intent is so costly, one corrective would be to return to bright-line rules for attested wills and reject both holographic and nuncupative ones. In most jurisdictions, that ship has already sailed; moreover, past formalism did

217. Those who seek attorneys for will drafting will not normally be "the nebulous testator."

218. See Jeffrey A. Schoenblum, Will Contests: An Empirical Study, 22 ReAL Prop. PRoB. \& TR. J. 607, 613, 617 (1987) (examining one county's probate records over a nine-year period and concluding that there was "no correlation between size of the estate and the likelihood of contest," but that in some cases, the motivation to challenge "derived from nonpecuniary impulses").

Similar reasons might discourage a vigorous defense to a will contest:

[T] he odor of the strike suit hangs heavily over this field. The beneficiaries named in the will are likely to be either charitable organizations whom the testator preferred to his relatives, or else those of his relatives and friends whom he loved most and who are most likely to want to spare his reputation from a capacity suit.

John H. Langbein, Living Probate: The Conservatorship Model, 77 MicH. L. REV. 63, 66 (1978) (footnote omitted).

219. Judith G. McMullen, Keeping Peace in the Family While You Are Resting in Peace: Making Sense of and Preventing Will Contests, 8 MARQ. ELDER'S ADVISOR 61, 81 (2006) (quoting Daphne Merkin, Mother of All Surrogates, N.Y. TIMES, May 14, 2006, § 6, at 74). Professor McMullen continues: "“[M]oney, she says, is never about money. It's about other things ... [u]sually anger and guilt.'” Id. at 80-81 (second alteration in original) (quoting Bob Morris, Stop Spending My Inheritance, N.Y. TIMES, July 30, 2006, § 9, at 3).

220. In many cases, testamentary intent is at issue in either its operational or interpretive sense. 
nothing to stanch the litigational tide it itself created. ${ }^{221}$ More substantively, merely retrenching strict intent doctrine and the rules for its expression is simplistic and dissatisfying if one admits the preeminence of intent and the freedoms it ensures.

\section{Actualizing Intent Through Testamentary Freedom}

\section{a. Decedent Wishes}

Property is commonly defined as a series of divisible rights relatively ordered among owners and things. ${ }^{222}$ Those rights, including transfer, can be variously stratified. For example, title can shift voluntarily or involuntarily, for consideration or without, and between the living or at the donor's death. The voluntary-transfer right is valuable irrespective of consideration. Sellers capitalize through dollars earned or costs foregone. Donors secure tax efficiencies, leverage, moral capital and bargaining power, ${ }^{223}$ ease of mind in providing for a necessitous beneficiary, and the purely altruistic pleasure of having made a gift, anonymously or otherwise. Giving self-actualizes. If donors did not benefit, gifts would not be made.

As a death-deferred gift, wills temper some of these values but strengthen others, perhaps because they are partially realized upon a will's execution as well as its probate. Writing a will is an intensely personal act, requiring its executor to confront simultaneously three interrelated issues, each difficult enough alone: economic position, interpersonal relationship, and mortality. ${ }^{224}$ By encouraging saving over spending, recognition of the will preserves economic stability for testators, beneficiaries, and the society within which they live. ${ }^{225}$ But

221. See, e.g., In re Abram's Will, 77 P.2d 101, 103 (Okla. 1938) (lamenting the defeat of the testator's clear testamentary intent by her failure to meet statutory requirements).

222. See generally J.E. Penner, The "Bundle of Rights" Picture of Property, 43 UCLA L. REV. 711 (1996) (discussing conceptualization of property).

223. Donors can secure general status through gifts and patronage or, more individually, affect others' behavior through promise of a future gift or reminder of a past one. See generally Paul W. Tappan, The Sociology of Inheritance, in SOCIAL MEANING OF LEGAL CONCEPTS 54 (Edmond N. Cahn ed., 1948).

224. See, e.g., John Astrachan, Why People Don't Make Wills, 118 TR. \& EsT., Apr. 1979, at 45 (providing a psychiatrist's view to explain high percentages of intestate death).

225. See Lawrence Zelenak, The Reification of Metaphor: Income Taxes, Consumption Taxes and Human Capital, 51 TAX L. REV. 1, 16 n.67 (1995) (noting savings disincentive of bequest taxes on transferors). Because tax rates never reach $100 \%$, the savings disincentive would skyrocket were there no mechanism through which to transfer the property at all. 
more personally, it might protect autonomy even more than through the decision-making power illustrated through a routine gift.

Inter vivos gifts typically mark a holiday or an important occasion over the arc of the recipient's life-birthday, graduation, marriage, anniversary, retirement. Although the sentimentality of the property given presumably increases with the significance of the commemorated event, the property forming the gift is often highly fungible, as with money or a gift card, or newly purchased, with neither preexisting connection to the donor nor intent for retention or use save its relatively immediate transfer to the donee. The donee may be a close friend or a virtual stranger. Unless the gift was motivated by donee need rather than donor largesse, post-gift assessment of its recipient's economic position is normally irrelevant to the donor and, where it is, can be factored into future donative transfers to secure the donee's continued well-being.

Testamentary gifts stand in stark contrast. "Although some testamentary instruments contain broad and generic distributive clauses, many testators instead specifically match devises with devisees, rendering both the res and the entitlement to its testamentary transfer 'personal.",226 The subject property is normally not purchased with a view to transferring it away, but is already owned by the testator and may hold personal and sentimental value quite distinct from traditional economic worth. More than a neighbor or colleague or the child of the same, the beneficiary of a deathtime gift is usually the testator's own spouse or child, parent or sibling, or the functional equivalent of a close partner or friend, irrespective of need- or blood-based criteria. The triggering event happens to the donor, not the donee, and is not a celebratory event. It is death, and it results in the last, and thus, unadjustable expression of intent that the decedent will ever make. If writing a will is person- and family-constitutive, the only intent that should matter for both process and result is the decedent's. That others could hold a different intent or express it alternatively should be irrelevant. First, there is a human inclination to think "I would have done that differently" or even "I would not have done that at all" when considering another's intent or action. Disposition toward such critique is probably greater where, as here, the context is universal and contains such fundamental elements as property, family, life, and death. When all parties are alive as through inter vivos transfer, sharing that critical 
sentiment with another might be well-received or not. Influence aside, the choice over whether to move forward from intent on through conduct will remain with the actor. When the actor, however, has already died, "sharing that sentiment" moves from observation into actual power: a challenger's contest, a bench or jury determination that no testamentary intent exists, and in a context where the testator is unavailable to clarify, correct misimpression, or responsively change course. ${ }^{227}$

In consequence, testamentary intent-imprecise, difficult to establish, emotionally fraught-becomes even more malleable, subject either to an innocently transferred factfinder impression over what they would have, thus what the decedent "must have," wanted, or more rawly, what the decedent "should have wanted" even if he did not. ${ }^{228}$ This potential invites speculation over whether a given holding might reflect the result orientation, and thus intent, of those decision makers more than the actual desires of the decedent, ${ }^{229}$ and it renders the jurisdiction's intestacy scheme critical if the outcome is to set aside a document as no will at all. ${ }^{230}$ Ambiguity factored by indeterminacy also worsens

227. An exception could exist in unlikely examples, such as a holographic letter's recipient requesting the testator to formalize things through a validly attested will.

228. See, e.g., Langbein, Will Contests, supra note 216, at 2043 ("Our fundamental value in the law of wills is freedom of testation, but the inner tendencies of civil jury trial put our procedural system in conflict with our substantive law. ... [B]ecause jurors who decide without giving reasons have such latitude to substitute their wishes for the testator's.”).

229. Scholarship on will contests that studies the reversal rate of jury determinations on appeal illuminates. See Josef Athanas, Comment, The Pros and Cons of Jury Trials in Will Contests, 1990 U. CHI. LEGAL F. 529, 545-46 (noting an early Minnesota study of testamentary undue influence cases finding that jury verdicts were up to six times more likely to be reversed than those rendered by the trial judge); Note, Will Contests on Trial, 6 STAN. L. REV. 91, 92 nn.4-5 (1953) (noting that although the jury in California found for the contestant in 77\% of will contests filed between 1892 and 1953, 62\% of those verdicts were reversed by the Supreme Court of California). Critique could be levied against the judiciary as well, if the rule of law is endemically value-laden in application. See, e.g., Erwin Chemerinsky, Getting Beyond Formalism in Constitutional Law: Constitutional Theory Matters, 54 OKLA. L. REV. 1 (2001) (discussing formalism and value choices in constitutional adjudication).

For scholarship discussing bias in results, see Mark Glover, Formal Execution and Informal Revocation: Manifestations of Probate's Family Protection Policy, 34 OKLA. CITY U. L. REV. 411 (2009); Melanie B. Leslie, The Myth of Testamentary Freedom, 38 ARIZ. L. REV. 235, 236-37 (1996); Kevin Noble Maillard, The Color of Testamentary Freedom, 62 SMU L. REV. 1783 (2009); E. Gary Spitko, Gone But Not Conforming: Protecting the Abhorrent Testator from Majoritarian Cultural Norms Through Minority-Culture Arbitration, 49 CASE W. RES. L. REV. 275 (1999).

230. See, e.g., Frances H. Foster, The Family Paradigm of Inheritance Law, 80 N.C. L. REV. 199, 228-33 (2001) [hereinafter Foster, Paradigm] (discussing efforts to redefine family to improve inheritance process); Frances H. Foster, Individualized Justice in Disputes Over Dead Bodies, 61 VAND. L. REV. 1351 (2008) [hereinafter Foster, Individualized Justice] (discussing disposition of a decedent's remains under American law); Susan N. Gary, We Are Family: The Definition of Parent and Child for Succession Purposes, 34 AM. ColL. TR. \& EsT. Couns. L.J. 171 (2008) (discussing 
doctrinal incoherence, as where courts legitimately strive to effectuate a particular decedent's intent but do so through tortured analysis or nonuniform latitude regarding its definition, timing, purpose, and proof.

Ironically, intent - the very subjective component that can override rules - is itself rendered vulnerable to its own override, operating like a blank screen upon which others can project themselves as actors or those acted upon, innocently coloring their view of the testator's desires or more intentionally shading its signals in desired ways. Such distortion would be minimized were the doctrine of testamentary intent better developed in substance and in proof.

\section{b. Societal Goals}

Accepting an individual's will into probate actualizes that individual's testamentary intent, a desirable outcome standing alone. Aggregated, however, doing so also animates the core value of testamentary freedom, doctrinal respect for which legitimates the policies of autonomy, self-definition and actualization, and self-determination that law serves.

\section{i. Testamentary Freedom in General}

Testamentary freedom is volition-whether to write a will at all, and if so, over what items, in what amounts, and to whom. ${ }^{231}$ Like the property over which it is exercised, it captures the ability, or property right, to make a voluntary, free, deathtime transfer, which meshes well within basic ownership doctrine as well as its donative and contractual freedom analogs. Moreover, testamentary freedom involves more than simply transfer. Exercising a transfer right to beneficiaries, itself a form of use and enjoyment, simultaneously exercises the right to exclude,

the definition of parent and child in intestacy statutes); E. Gary Spitko, The Expressive Function of Succession Law and the Merits of Non-Marital Inclusion, 41 ARIZ. L. REV. 1063, 1094-96 (1999) (discussing traditional succession law and the effect on the nontraditional family). See generally RALPH C. BRASHIER, INHERITANCE LAW AND THE EVOLVING FAMILY (2004) (comprehensively capturing the literature and discussing the realities of modern family in relation to inheritance law).

231. For assorted reasons ranging between intention, ignorance, avoidance, and oversight, most decedents will not exercise testamentary freedom, instead defaulting to a state's legislative determination of how property should devolve. See, e.g., Astrachan, supra note 224, at 45 (noting that in 1977 in New York it was likely that up to 50\% of decedents left no will). To the extent that the state scheme reflects the wishes of most people, most of the time, intestate death is not a total abandonment of personal preferences or utilitarian outcomes, at least for those whose wishes, if known, would fit within majoritarian norms. 
preventing acquisition by would-be heirs through intestacy or the state through escheat. It is also highly prized. Courts have described testamentary freedom as among "the most sacred rights attached to property"232 and "ancient and precious[,] ... running from the dawn of civilization in an unbroken line down to the present day."233 Breathless as they are, such words would not be used were they entirely untrue.

Testamentary freedom is a statutory creature, unquestionably regulated $^{234}$ and arguably existing solely by legislative grace. Under the now-familiar maxim, "the dead hand rules succession only by sufferance."235 Requiring that testamentary intent be expressed through a certain channel and in a certain way limits the freedom accorded the right, but is undoubtedly permissible in the same way that property in general can be limited by rules of substance and form. But the Supreme Court appreciates its functional constitutionalization by characterizing testamentary freedom as "an extraordinarily valuable right over which restraint must be carefully exercised" 236 and an integral part of AngloAmerican jurisprudence since feudalism, with abridgement deserving heedful scrutiny. ${ }^{237}$

\section{ii. Protecting Testamentary Freedom}

Formalities limit testamentary freedom by restricting expressive form. The same can be said of the doctrines of testamentary capacity or undue influence, which can invalidate wills otherwise compliantly

232. In re Estate of Foss, 202 A.2d 554, 558 (Me. 1964) (citing Deering v. Adams, 37 Me. 264, 269 (1853)).

233. Minary v. Citizens Fid. Bank \& Trust Co., 419 S.W.2d 340, 344 (Ky. 1967). See generally 2 BLACKSTONE, supra note 77, at 10-11 ("[T] he universal law of almost every nation (which is a kind of secondary law of nature) has either given the dying person a power of continuing his property, by disposing of his possessions [either] by will [or by statute] ....”).

234. Katheleen R. Guzman, Property, Progeny, Body Part: Assisted Reproduction and the Transfer of Wealth, 31 U.C. DAVIS L. REV. 193, 214 (1997). No property right is absolute; all bend to countervailing concerns when government regulates or even acquires them. Within the testamentary-freedom context, limits issue on both procedural, e.g., the formalities themselves, and substantive levels. For example, testamentary freedom over all property is limited by age and capacity requirements and public policy concerns; testamentary freedom over some property is limited by mortmain legislation, legitime, and elective share statutes or survivorship rights. See generally id. at 214-16 (discussing general testamentary principles).

235. Irving Trust Co. v. Day, 314 U.S. 556, 562 (1942).

236. Guzman, supra note 226, at 636 (citing Hodel v. Irving, 481 U.S. 704, 715-16 (1987)).

237. See Hodel, 481 U.S. at 715-16 (citing United States v. Perkins, 163 U.S. 625, 627-28 (1896)). 
expressed. $^{238}$ But each of these doctrines has as much to do with protection as limitation. Dismissing the expression of testamentary intent by precluding its formation by a testator lacking baseline mental ability theoretically protects decedents from themselves, and finding undue influence - or its variant, fraud ${ }^{239}$ - determines that the intent as expressed was not really that of the testator at all. ${ }^{240}$ Whether either doctrine serves its intended goals, both position against the probate of a seemingly valid will in ways that, like an intent-formalities coalition, prove law's commitment to safeguarding the integrity of volitional willmaking processes and results, and, therefore, to testamentary freedom.

In part, there lies the tension. Law is willing to engage in occasionally freewheeling exercises, through open evidentiary channels, to find that a particular testator either could not or did not mean what she said. In short, law backs into the protection of testamentary freedom, even against highly formal, attested documents, through will-contest doctrine. Why not engage these questions directly through more meaningful, direct attention? If testamentary freedom is precious and sacred $^{241}$ and if its abridgement deserves heedful scrutiny, ${ }^{242}$ so too do the millions of individualized intents that together give it life. After all, the concept of testamentary freedom is just that-a mere conceptunless it is effectuated through individuals' intent.

\section{B. Reworking Testamentary Intent}

Ad hoc acceptance of individual instruments into probate where the facts are hard and certain outcomes are sorely desired-by the decedent, the factfinders, or both-does not alleviate doctrinal problems. In fact, it creates as many difficulties as it solves. Appeals would not be uncommon for documents that seem non-testamentary on their face, and whether at trial or on appeal, judicially stretching extant doctrine to cover testamentary intent essentially ignores precedent and undermines respect for the law. Moreover, litigation again increases as indeterminate

\footnotetext{
238. See Daniel C. Marson et al., Testamentary Capacity and Undue Influence in the Elderly: A Jurisprudent Therapy Perspective, 28 LAW \& PsychoL. REV. 71, 71 (2004).

239. Pamela Champine, Expertise and Instinct in the Assessment of Testamentary Capacity, 51 VILL. L. REV. 25, 53 (2006).

240. See Marson et al., supra note 238, at 78-80 (describing undue influence in will execution).

241. See supra notes $232-33$ and accompanying text.

242. See Hodel, 481 U.S. at 714-15.
} 
outcomes encourage otherwise wary or resistant litigants to recalibrate their prospects and roll the dice.

Coupling high-value ends with inexpensive means to secure them is powerful, especially when positioned against low-value but expensive formalistic impediments to their attainment. That identifying testamentary intent can be "hard" or "easy" within an individualized judicial response is no longer sufficient. A more comprehensive strategy combining substantive and procedural avenues is called for, capable of removing unnecessary impediments to intent determination without sacrificing the protections that requiring it affords.

The suggestions that follow could be taken together or separately. Revisiting the cases earlier discussed through testamentary intent as reformed reveals that overlap often exists. Moreover, while the effect of the suggestions as applied is intrinsically affected by the governing jurisdiction's approach to documentary compliance, their thrust is directed toward the judicial concept of testamentary intent itself rather than legislative formulae for when it is met.

\section{Structural Reform}

As currently stated, testamentary intent is tightly hemmed, demanding that its holder intend a deathtime disposition of property through the specific document proffered. This definition should be broadened in two ways. First, neither the will nor the animus testandi impelling it should demand positive disposition of property at death and, instead, should simply reflect intent-governing probate distribution of an estate. This focal shift recognizes testamentary significance where, for example, a document does nothing more than identify an executor, disinherit an heir, or revoke an earlier will. Further, it also appropriately shields testamentary intent from that found within a will substitute. This change links with a second structural suggestion, which eliminates the requirement that the decedent have intended the precise document proffered to be "The Will." It should instead suffice that the decedent intended testamentary significance as expressed through the document rather than actually effectuated by it. If contracts can be formed without intending "a contract" 243 and if trusts can be created without calling them by name, ${ }^{244}$ so too should courts seek to effectuate a testamentary legal

243. See supra notes 196-97 and accompanying text.

244. RESTATEMENT (THIRD) OF TRUSTS $§ 13 \mathrm{cmt}$. a (2003). 
result, documentarily expressed, irrespective of its maker's view of the title to afford it or its instrumental effect.

The conventional formulation is not without merit. Tying a testator's deathtime dispositive intent through a precise instrument then at hand and now presented for probate increases seriousness in its execution and enhances its later evidentiary value. Such one-to-one mutual reinforcement of a will in both its "desire" and documentary senses limits trickery or mistaken over-inclusion, particularly where the document itself must meet some formality threshold. ${ }^{245}$ True, completely severing intent and specific documentation could inspire chaos, with words or conduct "transcribed then interpreted" after death into some recognizable form heavily affected by the hand of its transcriber. Nevertheless, existing agitation between intent and formalities already demonstrates that some ties are simply more tight than faithfulness to testamentary freedom should invite. Moreover, such criticism overstates the issue. As with formalities generally, it is unnecessary to pose antipodal extremes by presenting the choice as between an intent itself intended to be accomplished by one particular instrument and intent tied to nothing at all. ${ }^{246}$

The cost of retaining unnecessary, intent-defeating levels of inquiry with the potential to work great mischief on application outweighs the residual value in the current requirement. The definitional reformation here suggested adopts an intermediate position requiring some document-bridging intent and action, leaving the remaining questions as merely those of type.

245. Under the existing intent requirement of operational significance given to the particular instrument propounded, an often determinative component seems to arise where the casual instrument suggests that its recipient save it. See, e.g., Estate of Blake v. Benza, 587 P.2d 271, 272 (Ariz. Ct. App. 1978) (noting that after postscript stating that letter recipient "'can have my entire estate[,]”" writer admonished recipient to "'SAVE THIS'”); In re Estate of Kimmel, 123 A. 405, 405 (Pa. 1924) (““[L]ock [this letter] up [because] it may help you out.’”). See generally C.S. Parnell, Annotation, Letter as a Will or Codicil, 40 A.L.R.2d 698 (1955) (noting potential importance of words indicating writer's desire to keep document secret or retain it as proof). Nevertheless, the writer of a letter not containing such a fortuitous admonition may well feel the same way and either believe that no additional statement is necessary or fail to consider the issue at all.

246. See, e.g., John V. Orth, Wills Act Formalities: How Much Compliance Is Enough?, 43 REAL PROP. TR. \& EST. L.J. 73, 80 (2008) (critiquing formalities relaxation in part by suggesting that taken to its extreme, the trend would eventually result in simply trusting judges to discern what a particular decedent would have wanted). 


\section{a. Tying Testamentary Intent to a Rule-Compliant Document}

A modest possibility would counterbalance the loosened definition of testamentary intent with the requirement that the expressive document meet all execution requirements, themselves corroborating the writer's considered deliberation. This approach would probably not effect appreciable change and, in some instances, might even reverse the clock. For attested documents, it is unlikely that attached testamentary intent would be in question anyway. ${ }^{247}$ And as well as essentially devolving into a much-maligned formalism—although hustled in through intent rather than formality rules - statutory perfection is not even the majority approach given broad adoption of legislative and judicial corrective. Even where strict compliance still reigns, either for all wills or only holographic ones, it may be more stated than real with courts covertly excusing noncompliance by an interpretive light hand.

One avenue through which this approach may actually alter judicial outcomes, however, concerns the holographic will. ${ }^{248}$ The treatises are replete with instances where even an entirely handwritten, dated, and signed document complying with the strictest of jurisdictional rules is nevertheless denied probate for lack of testamentary intent. ${ }^{249}$ For example, in In re Moore's Estate, six days before committing suicide, the decedent signed and dated a letter that read, "Here is my ring. I leave you this and all that is mine.... Dont [sic] grieve for me. I love you. I'll leave a Will."250 The court refused to accept the document into probate, stating that it "clear[ly] and unambiguous[ly] ... negatives any idea that she considered the letter... to be a Will[, and o]n the contrary ... shows that some other writing yet to be made would be her Will."251 While the court was probably correct in its conviction, the decedent, if asked, presumably would have stated that she intended the specific testamentary result nevertheless. This should be sufficient. Were the definition of testamentary intent altered to require a showing of

247. See supra notes 18-19 and accompanying text. Aside from its presumptive intent-reflective terms discussed, circumstantial evidence of the document's safekeeping, such as being left with an attorney, filed with a court, or kept with other important papers, would likely suggest that its writer perceived it as a will through the traditional formulation of testamentary intent.

248. See, e.g., In re Estate of Serbousek, 751 N.W.2d 718, 719 (S.D. 2008) (reiterating its twostep approach taken in assessing a purported holograph: statutory compliance and testamentary intent).

249. See, e.g., 1 PAGE, supra note 20, § 5.14 (collecting cases).

250. 228 P.2d 66, 66-67 (Cal. Dist. Ct. App. 1951).

251. Id. at 68 . 
a compliant document's intended rather than operational effect, many more decedents would die with their wishes fulfilled.

This issue of present versus future will-making intent often arises where an individual requests that an attorney draft an initial will or change an existing one. ${ }^{252}$ Many jurisdictions follow the line of reasoning stated above to note that such a request is not, by definition, intended by the decedent to constitute her will. ${ }^{253}$ Again, the result may be overly harsh, particularly where the time between the request and the decedent's death is short. Compare contract law's treatment of letters of intent as, in certain cases, contracts themselves. ${ }^{254}$ Irrespective of the outcome reached in any particular case, revising the definition of testamentary intent may at least encourage more meaningful consideration of the intent question rather than glib invocation of an intent-defiant rule. Indeed, if courts are willing to disregard relatively clear manifestations of conditional intent as merely indicating the impetus for writing a will rather than the precise condition upon which it was to operate, perhaps they should consider the reverse possibility that instruction letters do indeed represent testamentary intent and, as with all wills, are conditional upon the testator's not having a later change of mind or of heart.

\section{b. Tying Testamentary Intent to the Casual Document}

Whether the relaxed version of testamentary intent can be found in casual documents is more troublesome. First, there is legitimate distinction between documents clearly attempted as wills but falling short of the rules and those not clearly attempted as wills whether rulecompliant or not. Again, the jurisdiction's means-ends take on compliance rules and intent effectuation will largely answer the question. ${ }^{255}$ This Article does not expressly advocate for excusing rules

252. See, e.g., In re Henry's Estate, 248 N.W. 853, 854 (Mich. 1933).

253. See, e.g., id. at 854-55 (signed and witnessed letter directing attorney's modification of existing will denying probate to); In re Will of Smith, 528 A.2d 918, 918-19 (N.J. 1987) (refusing probate of holographically compliant letter delivered to attorney stating "[m]y entire estate is to be left jointly to [my stepchildren]" as reflecting intended basis of will rather than will itself); In re Estate of Schiwetz, 102 S.W.3d 355, 362-64 (Tex. App. 2003) (declaring ineffective written instructions to attorney to make changes to existing will).

254. See, e.g., Thomas C. Homburger \& James R. Schueller, Letters of Intent-A Trap for the Unwary, 37 ReAl PROP. PROB. \& TR. J. 509, 513-18 (2002) (discussing three possible views of the letter of intent as (1) a binding and enforceable contract; (2) a contract to negotiate in good faith rather than consummate the contract; or (3) a term sheet creating no obligation at all).

255. See generally Brown, supra note 39, at 102-07 (addressing competing approaches to 
in favor of intent. But a "lack of testamentary intent" should not itself operate as an obdurate gatekeeper when it more than likely exists. That a non-compliant or even casual document might reflect it is not startling at all and, moreover, is what substantial-compliance and dispensation approaches already achieve when excusing rule compliance in a document's admission. ${ }^{256}$

Casual documentary expression is roughly divisible into immediate and deferred communicative acts. Immediate communicative acts exist where speakers publish messages to an audience. Within wills law, the most common versions evoked are instruction letters to attorneys, "promise" letters sent to those affected or benefitted by their terms, and third-party letters discussing prior or contemporaneous testamentary intent. Deferred communicative acts might include promise letters never sent; posthumously found letters addressed "to whom this may concern"; and unpublished diary entries or their equivalent. Unfortunately, many such forms fail under traditional intent structures-a person that sends a letter to his attorney requesting a modification to a will cannot have intended the letter itself to be a will. But this sort of reactionary rejection of testamentary intent should give way to a real consideration of whether the instrument nevertheless reflects testamentary significance before turning to the rule-compliance question. Each communicative form described above should be at least capable — especially where signed — of yielding testamentary intent as redefined irrespective of whether it also meets formal rules or is ultimately accepted into probate.

\section{c. Justifying Loosened Intent}

Broadening testamentary intent continues to makes sense when considered from the perspective of protecting testamentary freedom.

discerning testamentary intent in an ostensibly testamentary instrument).

256. See, e.g., UNIF. ProBate Code § 2-503 (amended 2008), 8 U.L.A. 146 (1998) (“Although a document ... was not executed in compliance with Section 2-502, the document or writing is treated as if it had ... if [its] proponent ... establishes by clear and convincing evidence that the decedent intended the document or writing to constitute ... the decedent's will ....”). Progressive as it generally is, here the Uniform Probate Code seems to have placed itself in a remarkably inconsistent position. Section 2-503 permits testamentary intent, implicitly defined as evidence that the decedent intended the document to constitute her will, to rescue a fully defective document. Id. By its own terms, however, it does not apply to compliant ones, presumably leaving the adopting jurisdiction's own definitions in place. $I d$.

Commentary to section 2-503 nevertheless stresses the inverse relationship between documentary noncompliance and the likelihood of proving testamentary intent through clear and convincing evidence. Id. § 2-503 cmt., 8 U.L.A. at 147. 
Documentary formalities and capacity rules are mainly justified by the protective functions they perform for the individual testator rather than her relatives or "the system." 257 If so, it is hard to see how refusing to grant testamentary significance to even casual documents that reflect itespecially handwritten and signed ones in a jurisdiction that recognizes holographic wills - is fair. Consider a simple example: $A$ writes a letter to $B$, stating "when I'm gone, all is yours." If $A$ later executes a valid will, then the relevant inquiry becomes whether any ostensible will that preceded it was thereby revoked in whole or in part. A's testamentary freedom remains protected irrespective of the presence or absence of testamentary intent accompanying the original letter. If $A$ does not later execute a valid will, however, $A$ 's heirs lose if the court accepts the letter as one; $B$ loses if the court does not. When $B$ loses, so does $A$, and testamentary freedom fades. Where courts straitjacket the intent doctrine, it is questionable whether $A$ is actually being protected, whether $A$ needs or deserves it, and whether there are superior ways to provide it.

Gift law is clearly solicitous of donors over donees by requiring delivery $^{258}$ or refusing to recast a failed gift as a self-declared trust. ${ }^{259}$ The rules sensibly encourage the existence of donative intent and compel its solid proof, which is particularly important where a donor lives on to regret the act. That transactions do not happen with oneself illuminates the seemingly inexplicable distinction with which law treats sellers. For example, by accepting the sufficiency of "the proverbial peppercorn, [or even] 'a horse or a canary [. . . if that is what] the promisee chose,",260 the law presumes that sellers need no protection beyond such basics as unconscionability or fraud, while interposing great formalism to protect the donor, and often from herself. Professor Jane Baron adroitly explains that the legal assumption that predominates about gifts is that donors are "fundamentally unreliable and deceitful," whereas bargainers in business are trusting, trustworthy, and reliable. ${ }^{261}$

257. See Langbein, Substantial Compliance, supra note 34, at 491-97.

258. See, e.g., Gruen v. Gruen, 496 N.E.2d 869, 872 (N.Y. 1986).

259. See RESTATEMENT (THIRD) OF TRUSTS § 16(2) (2003) (stating that intent to make an inter vivos gift unaccompanied by delivery will not be effectuated as a self-declared trust).

260. Weiner v. McGraw-Hill, Inc., 443 N.E.2d 441, 445 (N.Y. 1982) (citations omitted) (quoting Couldery v. Bartrum, (1881) 19 Ch. 394, 399).

261. Baron, supra note 41, at 157. Professor James Lindgren extends the point, observing slightly differently cast pejoration:

In the law of wills, the story told about people is that their seriously intended statements about their property can't be trusted. They are so weak, old, feeble, and subject to pressure that they need extraordinary protection from themselves. Their 
Some distinction lies in the fact that contract scenarios always implicate one party's intent, understanding, conduct, and reliance to check the other's, whereas in the testate context, the lone relevant intent is the testator's. But that seems to counsel even more to effectuating that one intent, even if somewhat imperfectly expressed, rather than treating each $A$ of the world as a fool, liar, or worse. If $A$ was a fool, that she is now dead inures her from personally experiencing any ill effects of an unwise bequest. True, direct evidence of $A$ 's intent is no longer available. But that not every criminal, tortfeasor, or contract breacher directly admits culpability has not deterred courts from rendering outcomes with far more serious liberty and property consequences than a determination that a now-decedent originally meant what she said. By refusing to probate casual documents, it is as though courts are dispensing more punishment than protection. And the "winners" will often be the heirs - conveniently, those whom the legislature has deemed worthy from the start.

Consider instead that in writing the letter, $A$ was a liar, or at least prone to dissembling. Attempted wills should effectuate freedom rather than recrimination. But if any "punishment" is to be had, it should set against one who communicates some testamentary intent to begin with by holding her to her word. If, as with contracts and some torts, law is willing to assign consequences where subjective intent does not exist, its refusal to do so where it manifestly does is puzzling. It is jarring, for example, to hold one who accidentally crosses another's land liable for trespass damages, yet utterly discount the salutary effects of a relatively clear writing through a peculiarly hard-bitten definition of testamentary intent. Admittedly, broadened judicial recognition of testamentary intent within casual documents could make writing them a risky enterprise, sending them even more so. ${ }^{262}$ But risk, like punishment, deters; deterrence, if rational, encourages. While the "casual testator" herself

spoken words are completely worthless. Their written statements are without meaning unless they're witnessed by two people. ... A And so on.

In the law of contracts, . . . the story is completely different. People are intelligent and competent. They know their own mind. Other people can rely on their seriously made statements. They don't need protection from themselves. Their spoken words are enough to convey millions of dollars. And their written statements have meaning without witnesses.

Lindgren, Formalism, supra note 9, at 1009 (footnotes omitted).

262. The notion is not new. See, e.g., McBride v. McBride, 67 Va. (26 Gratt.) 476 (1875) ("The mischief of converting private letters into wills — of clothing loose and unguarded expressions with the solemnities of testamentary acts-is too obvious to require comment or discussion.”). 
will be neither directly deterred nor capable of recidivism anyway, the overall legal signal sent could further enhanced deliberation and documents with cleaner expression or disavowal of testamentary intent. Given the tendency of rising and older generations alike toward text, email, or web-based correspondence, exploring intent within casual documents would be prudent now, before the likely onslaught of attempts to effectuate electronic documents and signatures begins.

Particular decedents may actually need and deserve protection from the consequences of their own acts, such as being pressured into leaving a document that benefits another. The documents that result should not be sifted out of probate by facilely applying strict intent-definitional rules. Instead, where facts warrant and relevant evidentiary standards were met, the doctrines of fraud, duress, coercion, testamentary capacity, and undue influence should suffice to backstop egregious results in particular estates. Recognizing their utility in such a safe-keeping role would be nothing new. For example, these doctrines are already invoked as providing sufficient safeguard when assessing whether a document substantially complies with the wills act or the effect of an interested witness on the validity of a will. ${ }^{263}$

Admittedly, wills law, including that of formalities and intent, is not solely about testator protection. First, it is also designed to shelter heirs. ${ }^{264}$ As incessantly repeated, however, an expectancy-the label assigned to an heir's expectant share or a will beneficiary's anticipated bequest - is not property. ${ }^{265}$ Thus, extinguishing it in an heir apparent by finding testamentary intent through more expansive interpretation would do nothing more than the law already allows. While the same could initially apply to putative beneficiaries under casual documents, a difference exists. For heirs, the expectancy arises in default of exercised testamentary freedom. For beneficiaries, it is affirmatively created"expected"-by its exercise and, therefore, should hold the dominant position. And beyond the protections that will contests already afford, spouses are likely ensured an elective share against a testate estate. If law's obsession with avoiding will over-inclusion reflects bias toward the protection of heirs over owners and beneficiaries, one wonders why

263. See, e.g., WASH. REV. CODE ANN. § 11.12.160 (West 2009) (beneficiary-witnessed will is not invalid, nor is beneficiary's interest necessarily purged, but a rebuttable presumption of duress, menace, fraud, or undue influence is created).

264. See, e.g., DUKEMINIER ET AL., supra note 8, at 215 (discussing use of purging statutes to protect non-witness heirs).

265. See Guzman, supra note 189, at 786. 
no jurisdiction save one ${ }^{266}$ has seen fit to extend similar guarantees to children. Reductio ad absurdum, perhaps individualized testamentary freedom is not as revered as the courts would have us think. Perhaps law should either let courts decide what a particular decedent should have wanted or allow legislative bodies to do the same through mandatory intestacy rules.

Second, wills law is also understandably concerned with maximizing the efficient use of judicial resources. ${ }^{267}$ Nevertheless, by contributing to the very qualitative mess that has engendered so much litigation to begin with, perhaps these branches should bear some of its corrective costs, erring, if at all, on the side of documentary inclusion pending judicious resolution of testamentary doctrine. Courts perform hard tasks all the time. That is their job. Moreover, as neither protection of heirs nor of systems has reached the near-constitutional level that testamentary freedom enjoys, rigorous search for individualized testamentary intent should prevail over the desire to manage any strain it might occasion.

\section{Procedural Reform}

A jurisdiction's willingness to excise the substantive requirements that a will both dispose of property and reflect the decedent's intent that the document itself should do it would diffuse some of the following concerns. Nevertheless, three stand-alone procedural moves, some of which already exist in specific jurisdictions, could improve the quality of testamentary-intent determination even if they end up taking far more time.

First, and irrespective of instrumental ambiguity, where a document is proffered as a will, a court should consider all evidence relevant to its maker's testamentary intent-whether documentary, oral, or circumstantial—and leave basic evidentiary rules to cover questions of relevance and the extent to which prejudicial harm outweighs probative value. So enhancing admissibility would decrease wasteful, peripheral litigation over the ambiguity of the document and the actual scope of applicable rules. Moreover, by affecting cost-value calculations for litigation, accepting that the contested document will not be the final

266. By constitutional and statutory authority, Louisiana is the only state with a limited forced heirship provision for descendants of a certain age, mental, or physical capacity. See LA. ConsT. art. 12 , § 5 .

267. See, e.g., DUKEMINIER ET AL., supra note 8, at 167 (discussing majority rule that, absent probable cause for a contest, enforces no-contest clauses to prevent unmeritorious litigation). 
"say" on the matter could even abate an initial filing or subsequent appeal. Extending evidentiary sources beyond the document itself would cure existing anomalies. If testamentary intent is so important that its presence can override a defective will or its absence vitiate a compliant one, it should be important enough to permit a search for its existence beyond a paper's four corners.

Second, as is already true for attested wills, a court should presume that the testator acted with testamentary intent for any document offered for probate-attested or holographic — that meets all of the jurisdiction's statutory requirements for a valid will. ${ }^{268}$ The burden of disproving testamentary intent would then rest upon challengers, ${ }^{269}$ again through a broad admissibility standard, by the traditional preponderance of the evidence for casual documents and clear and convincing evidence for duly attested ones. ${ }^{270}$ Finders of fact would remain free to make credibility assessments over witness testimony. This reform would align with existing presumptions over will revocation. While revocation, by reverting to a prior will or allowing the property to fall into intestacy, arguably effects substantive results at the same level as will execution, it—along with the intent that it requires-is presumed whenever a document known to have been in the testator's possession at death cannot be found thereafter. ${ }^{271}$ Courts willing to presume revocation through non-documentary negative implication should be equally, if not more amenable, to presume testamentary intent on signed documents regular on their face.

268. Note the traditional difference between a formally attested will — which permits a court to be "'reasonably certain"” that it was seriously intended-with a holograph, which leaves that question “'open to doubt.” 'Estate of Brown, 218 Cal. Rptr. 108, 110 (Cal. Ct. App. 1985) (quoting Gail Boreman Bird, Sleight of Handwriting: The Holographic Will in California, 32 HASTINGS L.J. 605, $632(1981)$ ).

269. See supra note 66 and accompanying text.

270. This shift in the standard is defensible given the high probability of testamentary intent in duly attested wills regular on their face and the quasi-fraudulent behavior of putative testators executing wills for some collateral purpose other than disposition at death. See supra notes 19-20 and accompanying text. Perhaps evidence more convincing than that an alleged testator was just joking, bluffing, or confused would demonstrate that she did not realize that she was signing a will. Such facts would probably involve fraud, an independent basis upon which to challenge a will, which ironically would suffer no extrinsic evidentiary bar in proving it because " fraud vitiates everything.” Grigg v. Hanna, 278 N.W. 125, 132 (Mich. 1938). Thus, cases such as In re Estate of Duemeland arise where immediately after pronouncing that "[o]nce it is shown that the will was properly executed, 'the executed will is the decedent's testamentary intent,"” the court pivoted to reminding that "[r]egarding testamentary intent . . . extrinsic evidence is not admissible except to show fraud or mistake.” 528 N.W.2d 369, 371 (N.D. 1995) (quoting In re Estate of Ostby, 479 N.W.2d 866, 871 (N.D. 1992)),

271. See supra note 63 and accompanying text. 
Third, where the document does not meet all jurisdictional rules but the substantial-compliance or harmless-error doctrines could possibly accept it into probate, then the burden of establishing testamentary intent should rest with its proponent. This is the current position espoused by both the Uniform Probate Code ${ }^{272}$ and the Restatement (Third) of Property. ${ }^{273}$ Both sources, however, require that the proponent establish intent through clear and convincing evidence. ${ }^{274}$ Admitting the difficulty of determining a decedent's intent, this standard nevertheless seems overly burdensome and should be replaced with the same preponderance rule as asserted for formality-compliant documents. ${ }^{275}$

\section{Reforms Applied}

Working both substantive and procedural ends might initially seem unduly expansive, but reprocessing the cases described earlier through such reform reveals that doing so not only improves particular outcomes, but indeed may merely legitimate that which is already covertly, and often inappropriately, done.

Dexter Johnson's handwritten and signed document leaving his brother a pittance at the close of a more detailed - but still invalidtyped document could have been deemed a valid holograph, thereby incorporating by reference the typed words of the paper on which it appeared. ${ }^{276}$ By so holding, the court would have upheld his testamentary intent directly and avoided the embarrassing contortion and mischievous result of essentially defining a will as any document with a testamentary flavor simply to permit its later "republication."277 Under this rule, Oral Fountain, who executed a handwritten and witnessed

272. Unif. Probate Code § 2-503 (amended 2008), 8 U.L.A. 146 (1998).

273. Restatement (THIRd) OF Prop.: Wills \& Other Donative Transfers $§ 3.3$ (1999).

274. Id.; UNIF. PROBATE CODE § 2-503, 8 U.L.A. at 146.

275. See generally Sherwin, supra note 38, at 460-62. Professor Sherwin cogently explains that failing to recognize testamentary intent is as bad as its identification where none exists-it is a disappointment exacerbated by imposing a clear-and-convincing requirement upon its proof. Id. Indeed, I would assert that failing to find it is, on balance, worse. See Lindgren, Formalism, supra note 9, at 1020 (noting that the problem of rejecting documents where testamentary intent seems clear "is not solved by the dispensing power, because... [it] is based on a high standard for testamentary intent, clear and convincing evidence," that "[t]o solve this problem, we need a lower standard of proof or more sensible judging," and that "[u]nder the new [Uniform Probate Code], we'll have to hope for the latter").

276. Johnson v. Johnson, 279 P.2d 928, 929-32 (Okla. 1954) (per curiam); see supra Part III.C.1.

277. See Johnson, 279 P.2d at 931-32. 
document captioned "Last Will and Testament" connecting specific property to each of her children's names, ${ }^{278}$ and who later informed her sister that she indeed had a will, ${ }^{279}$ would have died with her testamentary intent intact even though the writing she executed did not specifically use words of disposition. ${ }^{280}$ Charles Kuralt's letter to his paramour, clearly expressing his intent to provide for her at his death, could have been probated immediately rather than forced into expensive substantive and procedural litigation that may have ultimately accomplished Kuralt's wishes, but through avoidable doctrinal distortion. $^{281}$

By applying all of these reforms, costs could have been saved, serial litigation avoided, and outcomes enhanced. Moreover, irrespective of whether one agrees with, or even approves of, either an individual's conduct or her testamentary desire, that desire is what matters most if intent doctrine is to remain cognizant of the individualized desires that it serves.

\section{CONCLUSION}

Testamentary freedom and testamentary intent are twinned. As long as testamentary freedom remains a valued societal goal-and nothing suggests that it will not-effecting testamentary intent is crucial as the only means through which to secure it. Paradoxically, however, the enhanced position that testamentary intent has achieved-both directly at operational levels and indirectly through relaxed foreseeability and privity rules for estate planning malpractice, more thoughtful testamentary-capacity and undue-influence analysis regarding atypical estate plans, increased recognition, and even creation, of assorted will substitutes, and the very fall of formalism itself-has not been matched by concomitant rededication to understanding its twisted contours.

Inertia could explain this failure, especially if the task is perceived as either too hard or, more palatably, unnecessary given a perceived low incidence and level of trouble caused, faith in individual courts to reach appropriate ad hoc results, or the belief that other correctives have gone

278. Edmundson v. Estate of Fountain, 189 S.W.3d 427, 428 (Ark. 2004); see supra Part III.C.2.

279. Estate of Fountain, 189 S.W.3d at 429.

280. Cf. id. at 432. The document would have been presumed to have been executed with testamentary intent irrespective of its failure to reflect disposition on its face. Moreover, extrinsic evidence would have been admissible to establish such intent.

281. In re Estate of Kuralt, 15 P.3d 931 (Mont. 2000); see supra Part III.C.3. 
far enough. The notion that the perfect may be the enemy of the good does not mean that the good cannot be made better.

Part of the problem is unavoidable so long as wills create nothing in terms of experienced or actual realignment of rights. If testators feel no "wrench of delivery" in executing them, then they will be more casual about their creation. If beneficiaries feel indifferent to their creation, then they will be less insistent on formalization. Were the expectancy elevated to some point higher than its current legal purgatory, perhaps all parties involved would internalize the costs and benefits of will-making, then form intents and adjust signaling behaviors accordingly. That is unlikely in the short term, if ever.

An incomplete solution would simply be greater coherence at legislative, judicial, and theoretical levels over what testamentary intent is, how it must be expressed, what will suffice to establish it, and how it can be proved. But clarity alone is too timid a step. ${ }^{282}$ A more comprehensive strategy_one targeting readjustment of intent boundaries and increased pressure on its determinative capabilities-would better serve all the goals that wills are thought to express. The resurgence of academic literature asserting the need for enhanced sophistication in intestacy rules should suggest that default settings, particularly where they involve individual rights of extraordinary personal and societal magnitude, should not be too proud to give way to outcomes that respect intent.

More forgiving intent doctrine might be hard and might drive transition costs in the short term; capturing intent is never easy. But that is what courts are supposed to do. As the trial court judge somewhat paradoxically remarked during the trial over Charles Kuralt's will, "We're in a search for the truth, and we're going to pursue it with dispatch if it takes all summer."283 His words reveal that efficiency and justice can both be pursued. Long views appreciate where justice breaks down. They recognize the providence of time.

282. As Professor Myres McDougal lamented when writing about the torment of property complexities, "To make a superb inventory of Augean stables is not to cleanse them." Myres S. McDougal, Future Interests Restated: Tradition Versus Clarification and Reform, 55 HARV. L. REV. 1077, 1115 (1942) (reviewing RESTATEMENT OF PROP. (1940)).

283. In re Estate of Kuralt, 981 P.2d 771, 774 (Mont. 1999) (quoting the district court below). 